\title{
SERVBID: The Development of a B2C Service Brand Identity
} Scale

\begin{tabular}{|r|l|}
\hline Journal: & Journal of Services Marketing \\
\hline Manuscript ID & JSM-05-2019-0195.R2 \\
\hline Manuscript Type: & Article \\
\hline Keywords: & $\begin{array}{l}\text { Quantitative research, Service processes, servicescape, surveys, service } \\
\text { strategy, qualitative research }\end{array}$ \\
\hline \multicolumn{2}{|l}{} \\
\end{tabular}

\section{SCHOLARONE \\ Manuscripts}




\section{SERVBID: The Development of a B2C Service Brand Identity Scale}

\section{Structured Abstract}

Purpose: This paper re-conceptualizes and measures brand identity from a services perspective. It develops and tests a psychometrically valid and reliable scale to measure service brand identity.

Design/Methodology/Approach: A multi-stage research design was adopted drawing on qualitative and quantitative studies consistent with extant scale development procedures. Qualitative studies comprised comprehensive literature review, expert panel review and interviews to develop theoretical framework and generate items. Quantitative studies comprised pilot testing $(\mathrm{n}=106)$, online survey for scale development $(\mathrm{n}=245)$ and scale validation $(\mathrm{n}=246)$ on UK-based consumers using Exploratory and Confirmatory factor analysis.

Findings: The study finds support for a five-dimensional Service Brand Identity (SERVBID) scale comprising: process identity; organization identity; symbolic identity; servicescape identity; communication identity.

Practical Implications: The SERVBID scale provides practitioners with a practical tool to understand, benchmark and assess service brand identity. The scale will assist marketers in assessing the strength of brand identity overall as well as strength of individual facets of brand identity.

Originality/Value: This study provides a deeper and complete understanding of the theoretical construct of brand identity through a service-dominant lens, in particular recognizing the defining role of service process and servicescape in service brand identity construction.

Keywords Scale development, Brand Identity, Services Branding, Brand Loyalty, Brand Trust

Type: Research Paper 


\section{SERVBID: The Development of a B2C Service Brand Identity Scale}

\section{Introduction}

How do organizations develop brand identity? How is brand identity assessed? Does brand identity have an impact on consumer trust and loyalty? This study addresses these questions from the viewpoint of service organizations. Brand identity (BI) is an essential prerequisite for efficient brand management (Kapferer, 2012) and acts as an anchor of meaning for the brand (Csaba and Bengtsson, 2006) fulfilling consumers' symbolic and self-definitional needs for uniqueness (He at al., 2012). While a number of BI conceptual models and frameworks exist (e.g. Aaker, 1996; De Chernatony, 1999; Ghodeshwar, 2008; Burmann et al., 2009; Kapferer, 2012), they are largely conceived from a tangible goods perspective, mirroring wider branding research (Ostrom et al., 2010) and viewing BI as primarily a managerial construct (e.g. Aaker, 1996; De Chernatony, 1999; Coleman et al., 2011; Viot, 2011).

The current focus in branding has shifted from a 'detached-from-consumer' approach to one that recognizes consumers as key stakeholders and contributors engaging in the conceptualization and development of the brand and its identity (Kennedy and Guzman, 2016; Da Silveira et al., 2013). Prior conceptualizations of BI, now over two decades old, do not adequately reflect this view. Re-examining brand identity through a service-dominant lens allows a more experiential, interactive and dynamic view of brand identity.

The purpose of this study is to conceptualize and empirically validate BI from a consumer service perspective through the development of a service brand identity scale, which, we argue, is necessary for theoretical and practical reasons. First, from a theoretical perspective, we acknowledge the dominant and theoretically defining role of services and extend the conceptual domain of brand identity through the inclusion of services specific 
dimensions. To our knowledge, this has not been accounted for in extant research which has largely focused on brand identity from a goods-dominant perspective. In doing so, we contribute to and extend the literature on brand identity (e.g. Upshaw, 1995; Aaker, 1996; De Chernatony, 1999; Kapferer, 2000; Burmann et al., 2009; Coleman et al., 2011) to include attention to the service domain. As such, our findings provide a deeper understanding of the key dimensions of brand identity and suggest two key dimensions that are particularly relevant for services that have not been previously highlighted in the brand identity literature: process identity and servicescape identity.

Second, we provide a valid, reliable scale for assessing brand identity for service brands. Prior studies of BI are largely descriptive, suffer from a lack of empirical testing (Coleman et al., 2011), and a lack of consensus on what constitutes BI. Prior studies have largely advanced formative arguments on the role/importance of BI (Coleman et al., 2015). We present a rationale for modeling service brand identity as a higher-order formative construct.

Third, from a managerial perspective, successful management of a brand necessitates effective measurement. A valid, reliable service brand identity scale provides a tool by which service marketers/brand managers can improve their brand management efforts. Prior conceptualizations and measures provided only a partial view of brand identity and did not reflect the true assessment of services brand identity dimensions that might impact the development and subsequent maintenance of brand identity. Our scale provides a means by which managers can gain a deeper and more complete understanding of their brand's identity and the constituent dimensions. Brand managers can use the scale to assess the facets of the brand's identity that are performing well and those that are not in strengthening overall brand identity. This can help direct input in improving the overall effectiveness of their brand building efforts. 
We contend that the proposed service brand identity scale contributes to a greater and more complete understanding of the dimensionality of brand identity from a service-centered view that embraces process and experiential orientations. Our scale responds to calls for research in effectively branding services (Ostrom et al., 2010; Bitner, 2014) and contributes to a wider research effort that is seeking to re-envision branding from a service perspective and develop measurements specific to service branding (e.g. Völckner et al., 2010).

We begin with a comprehensive review of the literature to identify key dimensions of BI, integrating traditional goods-dominant perspectives on BI literature with service-relevant constructs. Then, from a methodological perspective, we develop the SERVBID ( Brand Identity) scale that empirically validates the key dimensions of service brand identity and provides a robust measurement of the construct. Finally, we test the applicability of the scale in predicting other consumer behavior outcomes (e.g. trust and loyalty).

\section{Conceptual Background}

\section{Construct Definition}

The term brand identity (BI) has been used to describe the essential idea of the brand (Aaker, 1996), the brand's specific and unique attributes (Kapferer, 2012), and its innermost substance (Csaba and Bengtsson, 2006). Given its multidimensionality, BI has been defined in different ways (Kennedy and Guzman, 2016; Da Silveira et al., 2013). Some common themes are discernible across these definitions. For instance, BI refers to the distinguishing features of the brand (what makes it unique, Kapferer, (2012)), the meaning of the brand (what the brand stands for, Aaker (1996)) and the attributes that define the brand (what makes it recognizable, Kapferer (2012)). Thus, we conceptualize the construct of Brand Identity as the sum of various attributes that define the brand, that give it distinguishable features and make it recognizable. 


\section{Domain of the Construct}

Brand identity is related to, but conceptually different from, other branding constructs. Table 1 compares brand identity to several other constructs to highlight the points of difference and further delineate $\mathrm{BI}$ as a unique construct.

[Insert Table 1 here]

The current branding literature recognizes that BI is a dynamic, multifaceted, multidimensional construct (Da Silveira et al., 2013; Coleman et al., 2013), which has been studied from a wide range of disciplines (Bravo et al., 2017). Consistent with this view, a number of BI frameworks have been put forward in the literature to describe BI and assist in its creation and management. Table 2 presents a brief summary of these frameworks.

[Insert Table 2 Here]

Albeit fundamental and informative, these frameworks largely adopt an individualistic perspective and do not directly account for the role of other stakeholders in constructing BI (Voyer et al., 2017). This could be attributed to the fact that these frameworks adopt a purely output orientation, which is most evident in the goods-dominant paradigm. Not surprisingly, this limits their applicability to a services context that embraces a process orientation. Drawing on the notion of the socially constructed nature of identity, Da Silveira et al. (2013, p. 28) propose a conceptualization of BI 'as dynamic and constructed over time through mutually influencing inputs from managers and other social constituents (e.g. consumers)'.

Acknowledging service to be the 'common denominator of exchange' (Merz et al., 2009, p.238), it is contended that there is a need to explore BI specifically from a service context that embraces a process orientation rather than a purely output orientation most evident in previous goods-dominant BI frameworks. 
Furthermore, BI research relies heavily on conceptualizing the construct from a managerial perspective, lacking account of other stakeholders, most prominently that of customers. This is in contrast to the view that firms now regard customer engagement and feedback as key inputs in shaping their BI (Kennedy and Guzman, 2016). While some research recognizes that the brand manager should not be the sole creator of a brand's identity (Csaba and Bengtsson, 2006; Schau et al., 2009, Prahalad and Ramaswamy, 2004; Iglesias et al., 2013), researchers have not yet adopted this in their empirical design. Amongst others, Iglesias et al. (2013), and Kennedy and Guzman (2016) caution brand managers from conceptualising brand identity without recognizing the power of customer inputs in its creation and shaping. This paper accounts for the consumer perspective of BI through qualitative (interviews) and quantitative (survey) research to shape, test and validate $\mathrm{BI}$ and its dimensions from a service perspective.

This study addresses the research gaps by developing and validating a measurement scale for service BI. The scale provides an empirically valid conceptualization of service BI and a means to measure the construct. Scale applicability is tested by assessing the impact of service BI on brand loyalty and brand trust - recognized as two of the most important consequences of BI (He at al., 2012).

\section{SERVBID Scale Development Process}

To develop the SERVBID scale, Churchill's (1979) paradigm was followed in conjunction with recommendations from DeVellis (2003) and other scale development studies (Brakus et al., 2009; Walsh and Beatty, 2007; Yoo and Donthu, 2001). A multistage research design was adopted to develop the final scale. First, an extensive literature review and semistructured interviews served as the primary basis for clarifying the domain of the construct and generating items. Second, a three-stage process was adopted to refine the generated 


\section{Construct specification}

To ascertain the domain of the construct, an in-depth review of literature was undertaken resulting in the identification of 21 different dimensions (see appendix A) of BI from various conceptualizations. Two independent academic experts were asked to review these dimensions to identify similar/overlapping areas and to re-group them into core groupings. This exercise resulted in four broad facets: brand-as-symbol, brand-as-product, brand-asorganization, brand-as-communication. They were labelled following Aaker's (1996) terminology to denote broad categories that encapsulate a wider set of attributes in the literature.

To ascertain a consumer perspective of the BI construct, face-to-face in-depth consumer interviews were conducted. Consistent with theoretical saturation (Glaser and Strauss, 1968) interviews were conducted until no new insights were generated; a total of eleven interviews. The interviews provided support for the four facets identified from the literature, while additionally suggesting three unique facets specific to the service context. Extending Aaker's labelling convention, these new facets were provisionally labelled as 'brand-asservicescape', 'brand-as-service process' and 'brand-as-service experience'. Overall, the construct specification process resulted in the identification of seven broad facets of BI to be further investigated as potential BI dimensions. 


\section{Item generation and content validity}

Items were generated for each of the seven service brand identity facets from extant measures in the literature and the interview transcripts. In stages one and two, two independent marketing academic experts were asked to review the items for clarity, conciseness, readability, relevancy or redundancy (DeVellis, 2003; Furr, 2011) thus ensuring content validity. This process resulted in the reduction of items from 79 to 47 .

In stage three, an independent expert panel comprising ten academic and managerial experts from the US and the UK evaluated the items. The panel review suggested that 12 items were not capturing the respective BI facet adequately thereby compromising content validity; consequently, these 12 items were eliminated. Overall, the process resulted in a refined set of 35 items with multiple items to represent each of the seven key facets of service BI.

Pilot survey $(n=106)$

An online pilot survey was administered to a convenience sample of 106 individuals recruited via social media. The sample comprised $47.2 \%$ female; $44.4 \%$ aged $20-29$ years and $17.6 \%$ aged $50-59$ years.

This sample size represented approximately $20 \%$ of the final sample, which was considered adequate for testing (Chisnall, 2001). The respondents were asked to think of a service brand that they have used in the past six months, and to indicate the extent to which they agree or disagree (on a 7-point Likert scale) that each of the items (statements) contribute to building brand identity for their chosen service brand. Next, the data collected was checked for any missing values or incomplete responses. However, apart from a few missing responses to classification questions (particularly nationality and income) all other responses were complete. At this stage, since the objective was to refine items, missing data 
on classification questions did not pose any difficulty. Hence, all the responses were included in the analysis.

A KMO of 0.80 indicated the suitability of the data for factor analysis. Exploratory factor analysis (EFA) (using principal components analysis and orthogonal rotation) was conducted primarily to refine the items. The analysis resulted in the deletion of six items based on low factor loadings $(<0.50)$, cross-loadings and low item-to-item correlations $(\mathrm{r}<$ 0.30) (Field 2009). The remaining item factor loadings ranged from 0.51 to 0.88 . This resulted in 29 items to be tested on a wider sample (Churchill, 1979).

\section{Measurement Model Specification}

We conceptualize the measurement model as a second-order formative construct with first-order reflective constructs. Given the lack of empirical studies on BI (as highlighted in Table 2), extant research remains silent on whether the relationship between brand identity and its dimensions is formative or reflective.

Applying Jarvis et al.'s (2003, p.203) decision rules for determining whether a construct is formative or reflective, we propose that the first-order dimensions of service brand identity must be formative indicators of the second-order 'service brand identity' construct, because together they are determining service brand identity rather than resulting from it. This also corresponds to our conceptually-derived definition of service brand identity. Thus, we contend that the first-order dimensions are not interchangeable, because each dimension captures a unique aspect of the construct domain.

Therefore, this research aims to develop a reflective first order and formative second order scale to measure service brand identity. In developing and validating formative constructs, we follow recommendations and guidelines provided by Jarvis et al. (2003), 
Diamantopoulos and Winklhofer (2001), Diamantopoulos et al. (2008), and Sarstedt et al. (2019).

\section{Study 1: Scale refinement and validation $(n=246)$}

This study aimed to empirically validate the 29 items using exploratory factor analysis. An online survey was administered to a sample of UK consumers using a permission-based mailing list from a list broker. To develop a generalizable scale that functions well in multiple service contexts, we asked respondents to complete the survey in reference to a brand from one of four services categories (airlines, banking services, hair salons or hotels). These services were identified from the interview stage and, according to Bitner's (1992) typology, represent a broad spectrum of services categories. Respondents were asked to select a service category and name their chosen brand.

Just under half (47.6\%) of respondents chose a brand in the banking sector, $24.8 \%$ chose an airline brand, $19.9 \%$ chose a hotel brand, while $7.7 \%$ chose a salon service brand. The survey asked respondents to indicate the extent to which they agreed/disagreed that each of the 29 items contributes to the development of the brand identity of their chosen service brand. Items were measured using a seven-point Likert scale anchored on 1 (strongly disagree) to 7 (strongly agree).

The sample $(\mathrm{n}=246)$ comprised $57.7 \%$ males, $42.3 \%$ females; $36.2 \%$ aged 55 years or above, $18.3 \%$ aged $45-54$ years, $17.9 \%$ aged $35-44$ years, $19.5 \%$ aged $25-43$ years.

Exploratory factor analysis (EFA) was used to assess the dimensionality of the scale and the appropriateness of the 29 items for capturing the dimensions of service BI. Prior to performing EFA the suitability of the data for EFA was assessed.

The Kaiser-Meyer-Olkin (KMO) measure of sampling adequacy was 0.92 and Bartlett's test of sphericity reached statistical significance $\left(\chi^{2}(378)=4432.97, p<0.001\right)$, supporting 
the factorability of the data (Hair et al. 2006). The correlation matrix revealed a substantial number of correlations of 0.3 and above (Walsh and Beatty, 2007; Hair et al., 2006) with the exception of one item that showed consistently low $(<.3)$ and insignificant $(p>.10)$ correlations with a large number of other items. Due to low correlations, this item was excluded from further analysis (Field, 2009), leaving 28 items.

\section{Exploratory Factor Analysis}

The remaining 28 items were subjected to EFA, using principal components analysis with orthogonal varimax rotation. Based on a minimum eigenvalue of 1 , a five-factor solution was extracted accounting for $68 \%$ of the cumulative total variance which is considered to be acceptable (Brace et al., 2003). Factor loadings and communalities of 0.5 and above were treated as significant (Hair at al., 2006). Two items demonstrating low communality $(<0.50)$ and low factor loading $(<0.5)$ were eliminated. There were no significant cross-loadings. The remaining factor loadings were significant and ranged between 0.52 and 0.84 .

Following Churchill (1979), the reliability of each factor was assessed using Cronbach's alpha; these ranged between 0.75 and 0.90 , indicating good internal consistency. This resulted in a five-factor 26-item structure. These five factors represented the initially proposed seven facets of BI but with greater parsimony.

Each of the five empirically-derived factors were labelled based on the core theme shared by its items (Field, 2009). The first factor was labelled Process Identity, because it contained items relating to the process of making the service brand available. The second factor contains items relating to the organizational image and reputational aspects of a service brand, such as organizational values projected by the brand and public relations activities. This factor was labelled Organization Identity. 
The third factor incorporates items that are related to the symbolic aspects of the brand such as name, logo, colour etc. This factor was labelled Symbolic Identity. The fourth factor contains three items that were conceptualized to form the originally proposed facet Brandas-Servicescape. This factor was re-labelled Servicescape Identity. The fifth factor contains items relating to the communication aspects that can contribute to building or reinforcing BI building. This factor was labelled Communication Identity.

The originally proposed facets Brand-as-Product and Brand-as-Experience did not emerge as distinct dimensions; the retained items making up these dimensions were subsumed into other dimensions, reflecting the intangibility of the service offering (product) as largely experienced as a process and emphasising the role of communication and symbolic representation of the brand. For example, the items originally proposed in the Brand-asExperience facet (e.g. 'Your relationship with the people providing brand $\mathrm{X}$ ' and 'Your relationship with other customers using brand $X^{\prime}$ ), were subsumed into the Brand-asProcess dimension. Items originally proposed under the Brand-as-Product facet were subsumed into the Brand-as-Symbol dimension (e.g. 'The country of origin of brand X'), and the Brand-as-Communication dimension (e.g. 'The value-added benefits offered by brand $\left.X^{\prime}\right)$.

\section{Checking for Common Method Variance (CMV)}

Harman's single-factor test is a commonly used technique to identify the issue of common method variance. However, researchers consider it to be a diagnostic technique rather than a statistical method (Podsakoff et al., 2003). Confirmatory factor analysis (CFA) is seen as a more sophisticated test to check for CMV. As a result, for this study CFA analysis using AMOS was used to identify and rule out any possible common method effects. Podsakoff et al. (2003) suggest using the single-method factor approach to check for any method biases 
at measurement level. This technique has been used and recommended by other studies (e.g. Elangovan and Xie, 2000; Widaman, 1985). Following this, we introduced a common latent variable (CLV) also referred to as method factor to the measurement model. We checked for model fit, with and without the CLV. If the introduction of CLV does not significantly improve the fit over the model without the CLV, then it demonstrates that the results are not affected by CMV. Also, the measurement model factors' loadings must continue to be significant in both cases (with and without CLV). The analysis results showed that the fit of the model did not improve significantly with the addition and specification of CLV over the specified measurement model alone.

The overall chi-square fit statistics for the original measurement model was $\chi^{2}(109)$ $=292.78, \mathrm{p}=0.000, \mathrm{GFI}=0.873$ ) while the fit statistics for the measurement model with CLV was $\left.\chi^{2}(124)=287.62, p=0.000, G F I=0.881\right)$. Although the overall chi-square fit statistics are significant, the incremental fit index yielded a rho of 0.014 which suggests insignificant improvement (Bentler and Bonnet, 1980). This indicates that method effects are insignificant. Additionally, the measurement model factor loadings were significant even after method effects were partialled out. Overall, these tests indicate that the results obtained through data analysis show true relationships among the variables and are not affected by CMV.

\section{Confirmatory Factor Analysis}

The five-factor model identified from EFA was further subjected to Confirmatory Factor Analysis (CFA) using AMOS. An initial inspection of model fit revealed marginal fit $\left(\chi^{2} / \mathrm{df}\right.$ $=3.11 ; \mathrm{CFI}=0.85 ; \mathrm{SRMR}=0.87$ and $\mathrm{TLI}=0.83$ ). This warranted further examination of the modification indices, standardized residuals, and standardized regressions weights to make re-estimation (MacCallum et al.1992; Hair et al., 2006; Furr, 2011). 
A sequential model modification approach (MacCallum et al., 1992) was adopted to improve its overall fit. Standardized regression weights (or estimated loadings) were reviewed to ensure they were all above the significant level of 0.5 . Modification indices were examined that identified three items with cross loadings (Jöreskog and Sorbom, 1988; Sin et al., 2005; Yoo and Donthu, 2001). Standardized residuals ideally should fall between 2.5 and 4.0 (Hair et al., 2006); items with values above 4.0 may be candidates for removal if they perform poorly on other criteria (Joreskog and Sorbom, 1988). Six items were outside these limits. Before making any decision to remove an item, authors considered how each item performed across all three parameters (i.e. standardized regression weights, modification indices, and standardized residuals). At the same time authors ensured close consultation with theory (McDonald and Ho, 2002) to preserve content validity.

The above process resulted in the removal of nine items. After re-specification and reestimation, the measurement model demonstrated an acceptable fit $\left(\chi^{2} / \mathrm{df}=2.15 ; \mathrm{CFI}=0.95\right.$; $\mathrm{SRMR}=0.05$ and $\mathrm{TLI}=0.93$ ). All the standardized loadings were above 0.50 indicating their statistical significance (see Table 3). The unstandardized loadings were also examined: for all items, t-values were significant $(\mathrm{p}<0.001)$ thus establishing the statistical significance of each loading. Thus, at the end of this stage, the final five factor 17-item SERVBID scale was obtained. This scale was further tested on a different sample (study 2) to establish its reliability and validity.

[Insert Table 3 here]

\section{Second-order measurement model validation (PLS-SEM)}

Study 2: Scale Validation using a Different Sample $(n=245)$ 
We conducted additional research to assess the proposed SERVBID scale's structure and properties. To prevent the problem of 'capitalization on chance' (MacCallum et al., 1992) and to assess the consistency of the underlying model from the previous analysis, the fivefactor SERVBID scale identified from study 1 was cross-validated on a different sample $(n=245)$ of UK-based customers (Churchill, 1979). Similar to study 1 data collection, an online survey was administered to a sample of UK consumers using a permission-based mailing list from a list broker. The objective was to cross-validate the scale and reconfirm the validity and reliability of the SERVBID scale (MacCallum et al., 1992; Anderson and Gerbing, 1988). Our additional objective was to assess the nomological validity of the scale. So, we included measures of brand trust and loyalty for this purpose. The results support the five-dimensional SERVBID scale. As shown in Table 3, all the reflective indicators load significantly on their respective factors, with loadings ranging from 0.69-0.92.

The validity of the formative dimensions was assessed through the significance and strength of the path (factor weights) from the particular dimension to the higher order construct. This is in line with the proposed approach by MacKenzie et al. (2005) and Sarstedt et al. (2019). Figure 1 shows that the weights for the five brand identity dimensions suggest that each dimension is an important determinant of Service Brand Identity (all the standardized weights were significant at $\mathrm{p}<.001$ and range between $0.16-0.34$ ).

\section{[Insert Figure 1 here]}

The composite reliability and Cronbach's alpha values were used to confirm the reliability of Service Brand Identity (SBI) dimensions. Table 4 shows that the composite reliability ranges from 0.86 to 0.92 , and Cronbach's alpha values were between 0.78 and 
0.89. Drawing on Hair et al. (2006) and Walsh and Beatty (2007), the validity of the scale was assessed based on three criteria: content validity, construct validity and, through application of the scale, nomological validity.

The content validity of the scale was established through high inter-item correlations and the results of qualitative analysis. Construct validity was established through convergent validity and discriminant validity. Convergent validity $(\mathrm{CV})$ assesses the extent to which measures that should be related to each other are in fact related. CV was not assessed based on Mackenzie et al.'s (2005) recommendations that the dimensions making up the formative construct (BI in this case) are not necessarily correlated. Discriminant validity (DV) provides evidence of the distinctiveness of each dimension of the scale. DV of the scale was assessed by comparing the AVE with the corresponding inter-construct squared correlations. All AVE values were greater than the inter-construct squared correlation, thus suggesting that the scale exhibits good discriminant validity.

\section{[Insert Table 4 here]}

\section{Nomological Validity}

Nomological validity is established when the scale behaves according to theoretical prediction (Westbrook, 1980). Nomological validity was established using two methods, as suggested by Hair et al. (2006). First, correlations among the proposed five dimensions of brand identity were examined to establish that they are positively related as theoretically predicted. Correlation estimates between each pair of factors were indeed positive and significant $(\mathrm{p}<0.001)$ (Table 4).

Second, to assess the nomological validity and scale applicability, we applied the scale to examine the relationship between the dimensions forming the higher-order service brand 
identity construct and other theoretically related constructs (Churchill, 1995). Literature identifies brand trust and brand loyalty as two key consequences of BI, suggesting a positive link between BI and trust (Burmann et al., 2009; Ghodeshwar, 2002) and BI and brand loyalty (He et al., 2012).

Ghodeshwar (2002) suggests that a strong BI, when communicated well and experienced positively by customers, results in the development of brand trust. The relationship between $\mathrm{BI}$ and trust can be visualized as a process that starts with BI that attracts consumers towards the brand (Schmitt and Simonson, 1997), consumers then build a relationship with the brand over time (Fournier, 1998) and develop trust that moderates in strengthening that relationship (Morgan and Hunt, 1994). On this basis, it is posited that there is a positive and significant relationship between service BI and trust. To measure brand trust, we adopted four standard trust items from Chaudhuri and Holbrook (2001): "I trust brand X"; "I rely on brand X"; "Brand X is an honest brand"; and "Brand X is safe."

Brand identity is argued to contribute to brand loyalty in several ways. It "helps in establishing a relationship between the brand and the customer by generating a value proposition involving functional, emotional, or self-expressive benefits" (Aaker, 1996, p.168). Strong brand-customer relationships elicit (or lay the foundation for) a behavioral response from customers such that they are more likely to prefer the product or service in the future and remain loyal (Oliver, 1999; Fournier and Yao, 1997). Customers may also display a high degree of commitment due to the unique set of associations of the brand (i.e. identity), thereby exhibiting affective loyalty. To the extent that loyalty is grounded in the existence of a valued relationship between the consumer and the brand (Oliver, 1999), it is expected that BI impacts brand loyalty directly and positively. We measured loyalty using five standard items from Yoo and Donthu's (2001) work: "In the future, I will be loyal to 
brand X"; "I will buy brand X again"; "Brand X will be my first choice in the future"; "I will not buy other brands if brand X is available"; and "I will recommend brand X to others."

The correlations between brand trust, brand loyalty and the dimensions of the brand identity were positive and significant $(\mathrm{p}<0.001)$ (Table 4). Overall, the measures correlated in a manner hypothesized by theory, thus confirming the nomological validity of the SERVBID scale.

\section{Results by Dimension}

The final SERVBID scale (Appendix B) is a short, easy to administer scale consisting of 17 items, which further increases its practical relevance in a professional context. The scale has been subject to various reliability and validity tests and can be used for both academic research as well as managerial practice. The scale comprises 5 dimensions:

Process identity encapsulates how the service is delivered/produced for consumers and the behaviour of or interaction with staff in the process. It emphasizes what Sirianni et al. (2013) refer to as the 'branded service encounter', recognizing the specific role of service interactions in delivering evidence of the brand and its positioning at every customer touch point. An organization's employees are particularly critical in building strong brands through service encounters as they represent the brand to customers (Wallace and De Chernatony, 2007). When the source of customer value shifts from the physical product offering to the service, frontline staff become key to delivering on promises and predominantly shape the consumer brand experience (Berry, 2000). Thus, BI is highly dependent on the actions and attitudes of staff (Punjaisri et al., 2009); 'strong and successful service brands are realized through positive employee behavior' (King and Grace, 2010, p. 939), and customers are 
sensitive to the behavior and attitudes of staff towards them during service encounters (Schlager et al., 2011).

Employees are an essential and critical stakeholder group that interact with customers and, thus, can influence BI management strategy for services (Löhndorf and Diamantopoulos, 2014). Given the intangibility of services, employees can shape customer perceptions towards the company brand (Papasolomou and Vrontis, 2006; Kimpakorn and Tocquer, 2010) and communicate and deliver brand promise to customers (Punjaisri and Wilson, 2011). More generally, Löhndorf and Diamantopoulos (2014) suggest that service firms need to develop their employees into 'brand champions'. They argue that 'people are motivated to maintain continuity in their self-concept ...A brand identity that matches an employee's sense of self can help maintain this consistent, stable self-concept, which has a positive effect on the employee's identification with the organization.' (p.314).

Organization identity refers to the organizational values, visions or ethos that represent the brand and make it recognizable at a strategic level. This dimension has strong theoretical priors, as evident in the literature review. Identifying and sustaining the values of a service brand is key to brand success. Zhang and Bloemer (2008) suggest that in a services context, values become especially important because they fill an evaluation void created by the absence of tangible functional attributes. Social responsibility values in particular can strategically enrich a company’s BI (Sen and Bhattacharya, 2001). Indeed, De Chernatony at al. (2004) identified that values represented the third most important theme for successful service brands after a focused position and consistency. A clear organizational vision provides a sense of direction for BI to proceed (Aaker, 1996; De Chernatony, 1999). The identity of a brand must be consistent with the company vision; inconsistencies between the communicated identity and company vision can create confusion in the minds of consumers thereby affecting the strength of BI. 
Symbolic identity encapsulates the signs and symbols used to represent the brand and its outer appearance; elements that have featured consistently in previous studies of BI (Aaker, 1996; Kapferer, 2012; Wheeler, 2012; Coleman et al., 2011). In addition to the traditional elements of brand name, logo/symbol, and colour associated with the brand, country of origin of the brand also emerged as a key symbol factor. There is evidence to suggest a link between country-of-origin and brand quality perceptions (Godey et al., 2012) which broadly contributes to overall BI.

Servicescape identity refers to the identity of the delivery environment, its ambience and atmosphere. The servicescape is the environment where the service is rendered and consumed (Nguyen, 2006) and is long recognized as a key factor affecting the quality of the service offering (Bitner, 1992). However, an explicit link has not been made previously between the potential for the servicescape to contribute to BI. The servicescape communicates cues to consumers of the capabilities and quality of the service firm and the identity and purpose of the service firm. This in turn is argued to create an impact on consumers in terms of their overall experience with the firm, their satisfaction, and loyalty towards the service brand (Bitner, 1992; Mayer et al., 2003; Harris and Ezeh, 2008). Since, $\mathrm{BI}$ is often described in terms of how a service may be perceived by the customers (Coleman et al., 2011), the servicescape elements have the potential to affect BI. This is also supported by Keller's (1993) assertion that the place where a service is delivered plays a key role in building brand associations in the customer's mind set. In a very practical sense, the servicescape provides a tangible and visual representation of the service brand, which contributes to its identity (Underwood et al., 2001). The servicescape dimension can apply equally well to physical environments and online environments.

Communication identity refers to the means by which the identity is communicated and any distinctive use of communication channels. The findings indicate that communication 
plays an important role in developing BI. Keller (1993) suggests that marketing communications exist as a way for firms to engage in dialogue with consumers and communicate their offerings. Furthermore, Duncan and Moriarty (1998) posit that communication channels help in generating a favourable response from consumers. Our results suggest that the nature of the communication (independent of the message) impacts on BI.

\section{Discussion and Conclusion}

We propose a novel and more inclusive definition of the construct of Service Brand Identity conceptualized as: the sum of process, organizational, symbolic, servicescape and communication attributes that define the brand, give it distinguishable features and make it recognizable. The need for a more holistic approach to consider key brand identity dimensions and to design a measurement tool emerged from both the academic literature and professional arena. The value and uniqueness of this paper lies in its novel conceptualization of service brand identity as a five-dimensional construct and the development of a theoretically consistent, valid and reliable measurement tool for the assessment of brand identity in a service context. Our study makes theoretical and practical contributions.

\section{Theoretical Contributions}

The findings extend initial studies on brand identity (e.g. Upshaw, 1995; Aaker, 1996; De Chernatony, 1999; Kapferer, 2000; Burmann et al., 2009; Coleman et al., 2011) by providing an updated and comprehensive investigation into brand identity and accounting for the dominant and theoretically defining role of services as recognized by various scholars.

There is some productive overlap between our study and extant literature, but two of the five factors (Process identity and Servicescape identity) are completely distinct and extend prior conceptualizations of brand identity that have not emphasized the role of service 
process and servicescape in developing or shaping brand identity. To the best of our knowledge, this scale is the first to make an explicit link between these dimensions and brand identity.

Process identity represents the critical role of service staff in building strong brands through service encounters as they represent the brand to customers (Wallace and De Chernatony, 2007). It plays an important role in delivering evidence of the brand and in positioning the brand at every customer touch point (Sirianni et al., 2013). In addition to this, Servicescape (or the delivery environment) emphasizes the tangible and visual representation of the service brand (Underwood et al., 2001).

This study also contributes to a more holistic and dynamic understanding of BI. Prior conceptualizations portray BI as a unilateral construct comprising the firm's view of how it wants the brand to be perceived (Coleman et al., 2011; Aaker, 1996; De Chernatony, 1999). The need to account for the consumer perspective in shaping and strengthening BI has been underlined by many scholars in recent studies (Kennedy and Guzman, 2016; Iglesias et al., 2013; Hatch and Schultz, 2010). In doing so, this research contributes by responding to calls for more research on marketing constructs that account for the consumer perspective (Payne et al., 2009; Kennedy and Guzman, 2016).

Overall, we provide a deeper and more complete understanding of the theoretical construct of BI through a service-dominant lens, in particular recognizing the defining role of people, processes and the delivery environment in developing the identity of the service brand.

\section{Managerial Contributions}

Businesses reportedly spend billions of dollars trying to create brand identities, yet many brands fail (Wheeler, 2003). To build a strong, unique and enduring brand identity managers 
need to understand what makes up their brand's identity, and be able to measure it effectively. Our research provides brand managers with: (a) a better understanding of what constitutes BI; (b) a diagnostic tool to observe and evaluate the identity of their brand; (c) a clarification of the impact of brand identity on customer relationships (through brand trust and loyalty); (d) a potential measurement tool to assess the performance and financial return of brand identity.

Our research provides managers with a better understanding of the constituent dimensions of their brand's identity, taking into account a more complete account of brand identity. Prior conceptualizations and BI measures have provided only a partial view of brand identity, accounting for largely a goods-dominant view of branding. Our scale takes account of service specific aspects which makes it more complete and relevant to today's brands, given that three of the top five global brands (Interbrand.com) in 2019 are largely service-based organizations (Google, Amazon, Microsoft).

Managers can use the SERVBID scale as a diagnostic tool to assess the relative importance of individual dimensions on overall brand identity. Brand managers can use the scale to assess which facets of a brand's identity are contributing positively or negatively to the overall identity of the brand. This can help guide brand management input in improving the overall effectiveness of their brand building efforts. For example, managers might use the tool to identify particular area(s) (e.g. service process, communication, and servicescape) that require support or attention.

The SERVBID scale also provides managers with a valuable barometer by which to gauge the performance of the brand. This may be achieved by using the scale (a) as a reference point for the measurement of KPIs in relation to individual aspects of the brand's identity; (b) to benchmark against competitor brands; or (c) to track the relationship between brand identity and key performance metrics, such as brand equity, sales or customer 
relationship metrics (e.g. satisfaction, loyalty). Used in this way, managers can understand how the overall brand identity or individual aspects of it relate to return on investment.

Understanding the importance of the different dimensions of BI should be useful in helping brand managers to develop more sophisticated segmentation and positioning and communication strategies. Research shows that brand identity has a positive impact on brand communication and brand strategy (Melewar et al., 2017). The SERVBID scale can assist managers in understanding the impact of each of the scale's dimensions on brand strategy and controlled and uncontrolled communication. This can contribute to managers overall efforts in brand building strategies.

\section{Limitations and Future Directions}

The limitations of this research may act as potential avenues for future research. Whilst this research has extended the traditional unilateral view of BI by incorporating a consumer perspective, further research could focus on applying the scale in a variety of contexts and explore a wider range of consequences as well as potential antecedents.

Our study accounted for four service brand categories (banks, hotels, airlines and salon services). There is scope to apply the scale to an extended range of service brands and explore potential differences between brands and service categories with regards to brand identity dimensions. Linked to this, further research could explore the settings in which the service brand is delivered to ascertain the impact on various levels of brand identity. The scale could be used explicitly to explore service BI in offline and online environments and in comparing service situations that vary in the degree of customer involvement or cocreation.

We focused on two key potential consequences of brand identity: brand loyalty and brand trust. Further research could explore a wider range of potential consequences, in particular those related to the financial performance of the brand. Research might usefully seek to 
evaluate the link between service BI and pricing (Csaba and Bengtsson, 2006) and service brand equity (Madhavaram et al., 2005). In doing so, it may be possible to ascertain the financial impact of individual dimensions of brand identity, enabling brand managers to target investment in those facets of a brand's identity that yield a higher financial return.

Productive links might also be explored between self-image/identity (both actual and ideal) and brand identity using congruence theory. Congruence theory (Sirgy, 1982) suggests that an individual's behavior would be regulated by the congruence between their perception of a brand's identity and their own self-image/identity. Further research could usefully explore the extent to which self-image/identity may serve as potential antecedents or consequences.

Another avenue for investigation could be brand communities (Fournier, 1998) and brand identity, exploring the interplay between different brand relationships and brand identity, such as brand tribalism. Indeed, taking a stakeholder approach to the development of brand identity, brand communities could be explored in terms of their shaping of brand identity.

Linked to the above, research could use the scale to understand and measure service BI from the perspectives of both consumers and firms simultaneously and conduct a gap analysis in perceptions. This would enable a closer understanding of the interaction between the projected and perceived BI, referred to elsewhere as 'the brand face' and 'the consumer face' (Da Silveira et al., 2013).

Finally, our research has been undertaken in a single country context (the UK). The scale could usefully be applied in other country contexts and cultural contexts to confirm the scale's external validity and reliability. Such replication will provide a solid understanding of differences or similarities between consumers' perspectives on service BI in different cultures and would inform global brand marketing efforts. 


\section{REFERENCES}

Aaker, D. (1996), Building Strong Brands, New York: Free Press.

Aaker, J. L. (1997), “Dimensions of brand personality”, Journal of Marketing Research, Vol. 34 No. 2, pp. 347-356.

Alsem, K. J. and Kostelijk, E. (2008), "Identity based marketing: A new balanced marketing paradigm", European Journal of Marketing, Vol. 42 No. 9/10, pp. 907-914.

Anderson, J. C. and Gerbing, D. W. (1988), "Structural equation modeling in practice: A review and recommended two-step approach”, Psychological Bulletin, Vol. 103 No. 3, pp. 411-423.

Berry, L. L. (2000), “Cultivating service brand equity”, Journal of the Academy of Marketing Science, Vol. 28 No. 1, pp. 128-137.

Bentler, P. M., and Bonett, D. G. (1980), "Significance tests and goodness of fit in the analysis of covariance structures”, Psychological bulletin, Vol. 88 No. 3, pp. 588.

Bitner, M. J. (1992), "Servicescapes: the impact of physical surroundings on customers and employees", Journal of Marketing, Vol. 56 No. 2, pp. 57-71.

Bitner, M. J. (2014), "Editorial: A vision for the future of the Journal of Service Research (JSR)", Journal of Service Research, Vol. 17 No. 1, pp. 3-4.

Brace N., Kemp, R. and Snelgar, R. (2003), SPSS for Psychologists, Basingstoke, UK: Palgrave Macmillan.

Brakus, J. J., Schmitt, B.H. and Zarantonello, L. (2009), "Brand experience: what is it? How is it measured? Does it affect loyalty?", Journal of Marketing, Vol. 73 No.3, pp. 52-68.

Bravo, R., B., de Chernatony, L and Martínez, E. (2017), "Managing brand identity: effects on the employees", International Journal of Bank Marketing, Vol. 35 No. 1, pp. 2-23.

Bullmore, J. (1984), "The Brand and its image revisited", International Journal of Advertising, Vol. 3 No. 3 , pp. $235-238$

Burmann, C., Hegner, S. and Riley, N (2009), “Towards an identity-based branding”, Marketing Theory, Vol. 9 No. 1, pp. 113-118.

Burmann, C., Jost-Benz, M. and Riley, N. (2009), "Towards an identity-based brand equity model”, Journal of Business Research, Vol. 62 No. 3, pp. 390-397.

Cadogan, J. W., Diamantopoulos, A. and De Mortanges, C. P. (1999), “A measure of export market orientation: scale development and cross-cultural validation", Journal of International Business Studies, Vol. 30 No. 4, pp. 689-707.

Chaudhuri, A. and Holbrook, M. B. (2001), "The chain of effects from brand trust and brand affect to brand performance: the role of brand loyalty”, Journal of Marketing, Vol. 65 No. 2, pp.81-93.

Churchill, G. A., Jr. (1979), “A paradigm for developing better measures of marketing constructs”, Journal of Marketing Research, Vol. 16 No. 1, pp. 64-73.

Coleman, D. A., de Chernatony, L. and Christodoulides, G. (2011), "B2B service brand identity: Scale development and validation", Industrial Marketing Management, Vol. 40 No. 7, pp. 1063-1071.

Coleman, D. A., de Chernatony, L., and Christodoulides, G. (2015), "B2B service brand identity and brand performance: an empirical investigation in the UK's B2B IT services sector", European Journal of Marketing, Vol. 49 No. 7/8, pp. 1139-1162.

Cretu, A. E. and Brodie, R. J. (2007), "The influence of brand image and company reputation where manufacturers market to small firms: A customer value perspective", Industrial Marketing Management, Vol. 36 No. 2, pp. 230-240.

Csaba, F. F. and Bengtsson, A. (2006), "Rethinking identity in brand management", In J. E. Schroeder and M. Salzer-Mörling (eds) Brand Culture, London: Routledge, pp. 118-135.

Da Silveira, C., Lages, C. and Simões, C. (2013), "Reconceptualizing brand identity in a dynamic environment", Journal of Business Research, Vol. 66 No. 1, pp. 28-36.

De Chernatony, L. (1999), "Brand management through narrowing the gap between brand identity and brand reputation”, Journal of Marketing Management, Vol. 15 No. 1/3, pp. 157-179. 
De Chernatony, L. (2010), "From Brand Vision to Brand Evaluation: The Strategic Process of Growing and Strengthening Brands, Abington, UK: Routledge.

De Chernatony, L., Drury, S. and Segal-Horn, S. (2004), “Identifying and sustaining services brands' values”, Journal of Marketing Communications, Vol. 10, pp. 73-93.

Delcourt, C., Gremler, D. D., van Riel, A. C., and van Birgelen, M. J. (2016), "Employee emotional competence: Construct conceptualization and validation of a customer-based measure", Journal of Service Research, Vol. 19 No. 1, pp. 72-87.

DeVellis, R. F. (2003), Scale development: Theory and Applications, California, CA: Sage.

Diamantopoulos, A., Riefler, P., and Roth, K. P. (2008), “Advancing formative measurement models”, Journal of business research, Vol. 61 No. 12, pp. 1203-1218.

Diamantopoulos, A., and Winklhofer, H. M. (2001). Index construction with formative indicators: An alternative to scale development. Journal of marketing research, Vol. 38 No. 2, pp. 269-277.

Duncan, T. and Moriarty, S. E. (1998), “A communication-based marketing model for managing relationships", Journal of Marketing, Vol. 62 No. 2, pp. 1-13.

Elangovan, A. R., and Lin Xie, J. (2000). Effects of perceived power of supervisor on subordinate work attitudes. Leadership \& Organization Development Journal, Vol. 21 No. 6, pp. 319-328.

Field, A. (2009), Discovering Statistics Using SPSS, London: Sage Publications.

Fournier, S. (1998), "Consumers and their brands: Developing relationship theory in consumer research", Journal of consumer research, Vol. 24 No. 4, pp. 343-373.

Fournier, S., and Yao, J. L. (1997), "Reviving brand loyalty: A reconceptualization within the framework of consumer-brand relationships", International Journal of research in Marketing, Vol. 14 No. 5, pp. 451472.

Furr, R. M. (2011), Scale Construction and Psychometrics for Social and Personality Psychology, London: Sage Publications.

Ghodeshwar, B. M. (2008), "Building brand identity in competitive markets: a conceptual model”, Journal of Product and Brand Management, Vol. 17 No. 1, pp. 4-12.

Glaser, B. G. and Strauss, A. L. (1968), The Discovery of Grounded Theory: Strategies for Qualitative Research, Chicago, IL: Aldine Publishing Company.

Godey, B., Pederzoli, D., Aiello, G., Donvito, R., Chan, P., Oh, H., Singh, R., Skorobogatykh, I.I., Tsuchiya, J. and Weitz, B. (2012), "Brand and country-of-origin effect on consumers' decision to purchase luxury products”, Journal of Business research, Vol. 65 No. 10, pp. 1461-1470.

Gotsi, M., and Wilson, A. M. (2001), "Corporate reputation: seeking a definition”, Corporate Communications: An International Journal, Vol. 6 No. 1, pp. 24-30.

Hair, J. F., Black, W., Babin, B., Anderson, R. E. and Tatham, R. L. (2006), Multivariate Data Analysis, Upper Saddle River, NJ: Pearson Prentice Hall.

Harris, L. C. and Ezeh, C (2008), "Servicescape and loyalty intentions: an empirical investigation", European Journal of Marketing, Vol. 42 No. 3/4, pp. 390-422

He, H., Li, Y. and Harris, L (2012), "Social identity perspective on brand loyalty", Journal of Business Research, Vol. 65 No. 5, pp. 648-657.

Iglesias, O., Ind, N., and Alfaro, M. (2013), "The organic view of the brand: A brand value co-creation model", Journal of Brand Management, Vol. 20 No. 8, pp. 670-688.

Jarvis, C. B., MacKenzie, S. B., and Podsakoff, P. M. (2003). A critical review of construct indicators and measurement model misspecification in marketing and consumer research. Journal of consumer research, Vol. 30 No. 2, pp. 199-218.

Jöreskog, K. G. and Sörbom, D (1988), LISREL 7: A Guide to the Program and Applications, Chicago, IL: SPSS.

Kapferer, J. N. (1997), Strategic Brand Management, London: Kogan Page.

Kapferer, J. N. (2000), Strategic Brand Management, New Delhi: Kogan Page. 
Kapferer, J. N. (2012), The new strategic brand management: Advanced insights and strategic thinking, Kogan page publishers.

Keller, K. L. (1993), “Conceptualizing, measuring, and managing customer-based brand equity”, Journal of Marketing, Vol. 57 No. 1, pp. 1-22.

King, C. and Grace, D (2010), "Building and measuring employee-based brand equity”, European Journal of Marketing, Vol. 44 No. 7/8, pp. 938-971.

Kennedy, E., and Guzmán, F. (2016), “Co-creation of brand identities: consumer and industry influence and motivations", Journal of Consumer Marketing, Vol. 33 No. 5, pp. 313-323.

Lau, G. T. and Lee, S. H. (1999), "Consumers' trust in a brand and the link to brand loyalty”, Journal of MarketFocused Management, Vol. 4 No. 4, pp. 341-370.

Löhndorf, B. and Diamantopoulos, A. (2014), "Internal Branding: Social Identity and Social Exchange Perspectives on Turning Employees into Brand Champions", Journal of Service Research, Vol. 17 No. 3, pp. 310-325.

Low, G. S., and Lamb Jr, C. W. (2000), “The measurement and dimensionality of brand associations", Journal of Product and Brand Management, Vol. 9 No. 6, pp. 350-370.

MacCallum, R. C., Roznowski, M. and Necowitz, L. B. (1992), "Model modifications in covariance structure analysis: The problem of capitalization on chance", Psychological Bulletin, Vol. 111 No. 3, pp. 490504.

MacKenzie, Scott B., Philip M. Podsakoff, and Cheryl Burke Jarvis (2005), “The Problem of Measurement Model Misspecification in Behavioral and Organizational Research and Some Recommended Solutions,' Journal of Applied Psychology, Vol. 90 No. 4, pp. 710-730.

Madhavaram, S., Badrinarayanan, V. and McDonald, R. E. (2005), "Integrated marketing communication (IMC) and brand identity as critical components of brand equity strategy: A conceptual framework and research propositions", Journal of Advertising, Vol. 34 No. 4, pp. 69-80.

Mayer, K. J., Bowen, J. T., and Moulton, M. R. (2003), “A proposed model of the descriptors of service process", Journal of services marketing, Vol. 17 No. 6, pp. 621-639.

McDonald, R. P., and Ho, M. H. R. (2002), "Principles and practice in reporting structural equation analyses", Psychological methods, Vol. 7 No. 1, pp. 64-82.

Melewar, T. C., Foroudi, P., Gupta, S., Kitchen, P. J., and Foroudi, M. M. (2017), "Integrating identity, strategy and communications for trust, loyalty and commitment", European Journal of Marketing, Vol. 51 No. 3, pp. 572-604.

Merz, M. A., He, Y. and Vargo, S. L. (2009), "The evolving brand logic: a service-dominant logic perspective", Journal of the Academy of Marketing Science, Vol. 37 No. 3, pp. 328-344.

Morgan, R. M. and Hunt, S.D. (1994), "The commitment-trust theory of relationship marketing”, Journal of Marketing, Vol. 58 No. 3, pp. 20-38.

Moorthi, Y. L. R. (2002), “An approach to branding services”, Journal of Services Marketing, Vol. 16 No. 3 , pp. 259-274.

Nguyen, N. (2006), "The collective impact of service workers and servicescape on the corporate image formation”, International Journal of Hospitality Management, Vol. 25 No. 2, pp. 227-244.

Oliver, R. L. (1999), “Whence consumer loyalty?”, Journal of Marketing, Vol. 63, No. 4, pp. 33-44.

Ostrom, A. L., Bitner, M. J., Brown, S. W., Burkhard, K. A., Goul, M., Smith-Daniels, V., Demirkan, H. and Rabinovich, E. (2010), "Moving forward and making a difference: research priorities for the science of service”, Journal of Service Research, Vol. 13 No. 1, pp. 4-36.

Padgett, D., and Allen, D. (1997), “Communicating experiences: a narrative approach to creating service brand image", Journal of Advertising, Vol. 26 No. 4, pp. 49-62.

Parasuraman, A., Zeithaml, V. L. and Berry, L. A. (1988), "SERVQUAL: A multiple item scale for measuring consumer perceptions of service quality”, Journal of Retailing, Vol. 64 No. 1, pp. 12-40.

Payne, A., Storbacka, K., Frow, P. and Knox, S. (2009), “Co-creating brands: Diagnosing and designing the relationship experience”, Journal of Business Research, Vol. 62 No.3, pp. 379-389. 
Podsakoff, P. M., MacKenzie, S. B., Lee, J. Y., and Podsakoff, N. P. (2003). Common method biases in behavioral research: A critical review of the literature and recommended remedies. Journal of applied psychology, Vol. 88 No. 5, pp. 879-903.

Prahalad, C. K., and Ramaswamy, V. (2004), "Co-creation experiences: The next practice in value creation", Journal of interactive marketing, Vol. 18 No.3, pp. 5-14.

Punjaisri, K., Wilson, A. and Evanschitzky, H. (2009), "Internal branding to influence employees' brand promise delivery: a case study in Thailand”, Journal of Service Management, Vol 20 No. 5, pp. 561579.

Sarstedt, M., Hair Jr, J. F., Cheah, J. H., Becker, J. M., and Ringle, C. M. (2019), "How to specify, estimate, and validate higher-order constructs in PLS-SEM", Australasian Marketing Journal, Vol. 27 No. 3, pp. 197-211

Schau, H. J., Muñiz Jr, A. M., and Arnould, E. J. (2009), "How brand community practices create value", Journal of marketing, Vol. 73 No. 5, pp. 30-51.

Schlager, T., Bodderas, M., Maas, P. and Cachelin, J. L. (2011), "The influence of the employer brand on employee attitudes relevant for service branding: An empirical investigation”, Journal of Services Marketing, Vol. 25 No. 7, pp. 497-508.

Schmitt, B. and Simonson, A. (1997), Marketing Aesthetics: The Strategic Management of Brands, Identity, and Image, New York, NY: Free Press.

Selnes, F. (1993), “An examination of the effect of product performance on brand reputation, satisfaction and loyalty”, European Journal of Marketing, Vol. 27 No. 9, pp. 19-35.

Sen, S. and Bhattacharya, C. B. (2001), "Does doing good always lead to doing better? Consumer reactions to corporate social responsibility”, Journal of Marketing Research, Vol. 38 No. 2, pp. 225-243.

Sirgy, M.J. (1982), "Self-concept in consumer behavior: a critical review", Journal of Consumer Research, Vol. 9 No. 3, pp. 287-300.

Sirianni, N. J., Bitner, M. J., Brown, S. W. and Mandel, N. (2013), "Branded service encounters: Strategically aligning employee behavior with the brand positioning", Journal of Marketing, Vol. 77 No. 6, pp. 108123.

Underwood, R., Bond, E. and Baer, R. (2001), "Building service brands via social identity: Lessons from the sports marketplace", Journal of Marketing Theory and Practice, Vol. 9 No. 1, pp. 1-13.

Upshaw, L. B. (1995), Building Brand Identity: A Strategy for Success in a Hostile Marketplace, New York, NJ: Wiley.

Vargo, S. L. and Lusch, R. F. (2004), "Evolving to a new dominant logic for marketing”, Journal of Marketing, Vol. 68 No.1, pp. 1-17.

Veloutsou, C., and Moutinho, L. (2009), "Brand relationships through brand reputation and brand tribalism", Journal of Business Research, Vol. 62 No. 3, pp. 314-322.

Viot, C. (2011), “Can brand identity predict brand extensions' success or failure?”, Journal of Product and Brand Management, Vol. 20 No. 3, pp. 216-227.

Voyer, B. G., Kastanakis, M. N., and Rhode, A. K. (2017), "Co-creating stakeholder and brand identities: A cross-cultural consumer perspective”, Journal of Business Research, Vol. 70, pp. 399-410.

Wallace, E. and de Chernatony, L. (2007), "Exploring managers' views about brand saboteur", Journal of Marketing Management, Vol. 23 No.1-2, pp. 91-106.

Walsh, G. and Beatty, S. E. (2007), “Customer-based corporate reputation of a service firm: scale development and validation”, Journal of the Academy of Marketing Science, Vol. 35 No.1, pp.127-143.

Westbrook, R.A. (1980), “A rating scale for measuring product/service satisfaction”, Journal of Marketing, Vol. 44 No. 4, pp. 68-72.

Widaman, K.F. (1985), "Hierarchically nested covariance structure models for multitrait- multimethod data", Applied Psychological Measurement, Vol. 9 No. 1, pp. 1-26. 
Williams, B., Brown, T. and Onsman, A. (2010), "Exploratory factor analysis: A five-step guide for novices", Australasian Journal of Paramedicine, Vol. 8 No. 3. Retrieved April 12, 2015 from http://ro.ecu.edu.au/jephc/vol8/iss3/1

Wheeler, A. (2003), Designing Brand Identity: A Complete Guide to Creating, Building, and Maintaining Strong Brands, Hoboken, NJ: John Wiley.

Yoo, B. and Donthu, N. (2001), "Developing and validating a multidimensional consumer-based brand equity scale", Journal of Business Research, Vol. 52 No. 1, pp. 1-14.

Zhang, J. and Bloemer, J. M. M. (2008), "The impact of value congruence on consumer-service brand relationships", Journal of Service Research, Vol. 11 No. 2, pp. 161-178. 
Table 1 Relationship between brand identity and other similar constructs

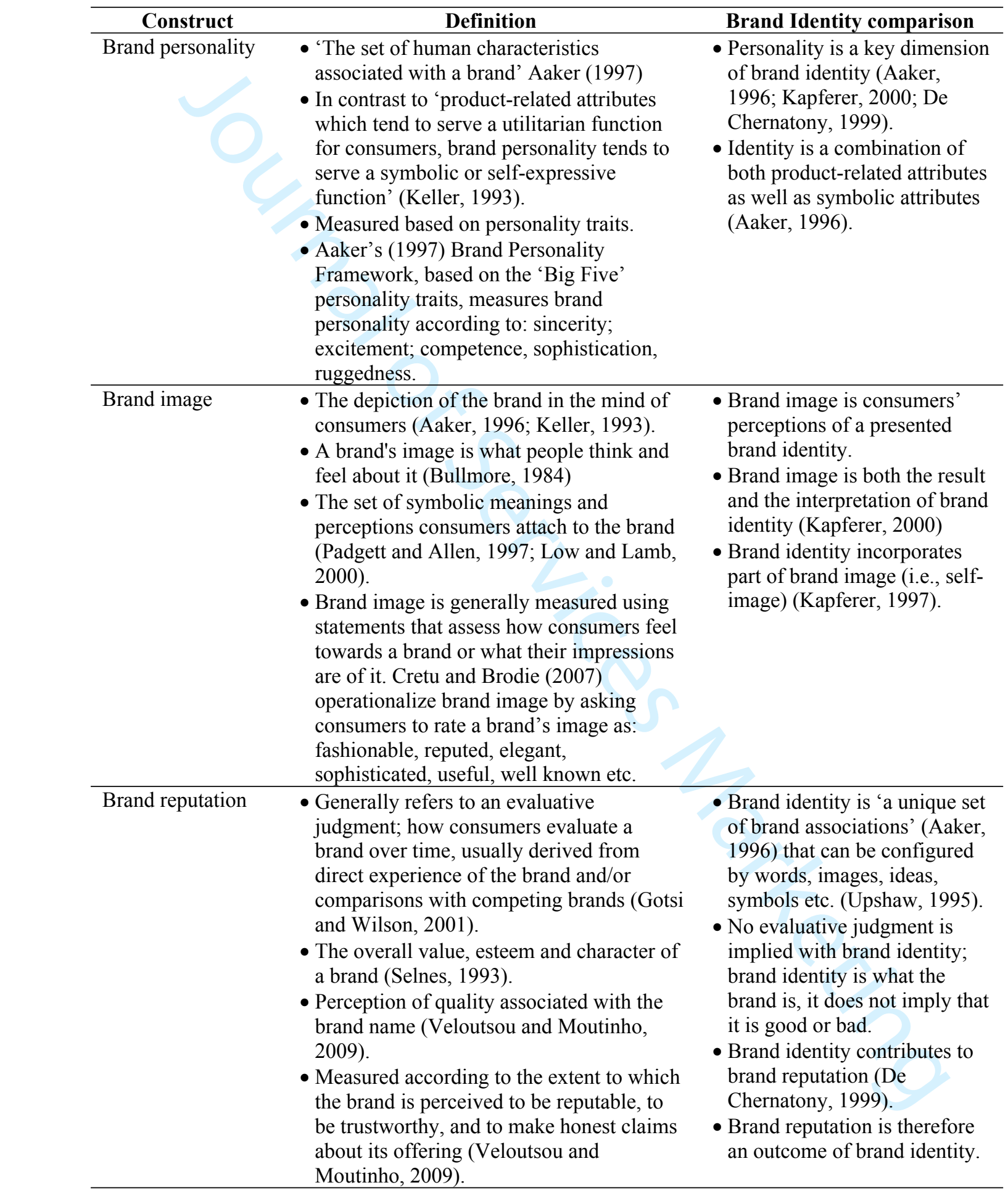

\section{Tables}

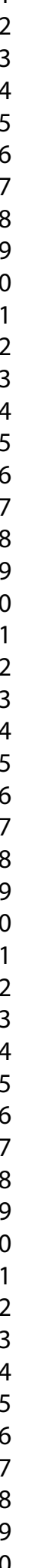
which tend to serve a utilitarian function for consumers, brand personality tends to expressive

- Measured based on personality traits.

Framework, based on the 'Big Five' personality traits, measures brand personality according to: sincerity; excitement; competence, sophistication, consumers (Aaker, 1996; Keller, 1993). feel about it (Bullmore, 1984)

- The set of symbolic meanings and 2000).

Brand image is generally measured using are of it. Cretu and Brodie (2007) perationalize brand image by asking sophisticated, useful, well known etc. judgment; how consumers evaluate a over time, usually derived from comparisons with competing brands (Gotsi Wilson, 2001) a brand (Selnes, 1993). and name (Veloutsou and Moutinho, Measured according to the extent to which the brand is perceived to be reputable, to about its offering (Veloutsou and

\author{
- Personality is a key dimension \\ 996; Kapferer, 2000; De \\ Chatony, 1999). \\ both product-related attribute \\ as well as symbolic attributes \\ (Aaker, 1996).
}

- Brand identity incorporates part of brand image (i.e., selfimage) (Kapferer, 1997). 
Table 2 Summary of key brand identity frameworks

\begin{tabular}{|c|c|c|c|}
\hline Citation & Construct definition & Construct dimensions & Study type \\
\hline $\begin{array}{l}\text { Aaker (1996, } \\
\text { p.68) }\end{array}$ & $\begin{array}{l}\text { 'a unique set of brand } \\
\text { associations that the brand } \\
\text { strategist aspires to create } \\
\text { or maintain.' }\end{array}$ & $\begin{array}{l}\text { Brand-as-product (product scope, } \\
\text { product attributes, quality/value, } \\
\text { uses, users, country of origin) } \\
\text { Brand-as-organization } \\
\text { (organizational attributes, local } \\
\text { versus global) } \\
\text { Brand-as-person } \\
\text { (brand personality, brand-customer } \\
\text { relationships) } \\
\text { Brand-as-symbol } \\
\text { (visual imagery/metaphors and } \\
\text { brand heritage). }\end{array}$ & $\begin{array}{l}\text { Conceptual } \\
\text { framework }\end{array}$ \\
\hline $\begin{array}{l}\text { Kapferer } \\
(2012)\end{array}$ & & $\begin{array}{l}\text { Physique } \\
\text { Personality } \\
\text { Culture } \\
\text { Relationship } \\
\text { Reflection } \\
\text { Self-Image }\end{array}$ & $\begin{array}{l}\text { Conceptual } \\
\text { Framework }\end{array}$ \\
\hline $\begin{array}{l}\text { De Chernatony } \\
(2006, p .45\end{array}$ & $\begin{array}{l}\text { 'the distinctive or central } \\
\text { idea of a brand and how the } \\
\text { brand communicates this } \\
\text { idea to its stakeholders }\end{array}$ & $\begin{array}{l}\text { Brand vision } \\
\text { Brand Culture } \\
\text { Brand Positioning } \\
\text { Brand Personality } \\
\text { Brand Relationships } \\
\text { Brand Presentation } \\
\end{array}$ & $\begin{array}{l}\text { Conceptual } \\
\text { Framework }\end{array}$ \\
\hline $\begin{array}{l}\text { Burmann et al. } \\
2009 \text { (p.115) }\end{array}$ & $\begin{array}{l}\text { (brand identity) 'can be } \\
\text { regarded as a type of group } \\
\text { identity, expressed through } \\
\text { various means like } \\
\text { competences, origin, vision, } \\
\text { communication style and } \\
\text { behaviour.' }\end{array}$ & $\begin{array}{l}\text { Brand Promise } \\
\text { Brand Behaviour } \\
\text { Brand experience } \\
\text { Brand Expectations }\end{array}$ & $\begin{array}{l}\text { Conceptual } \\
\text { Framework }\end{array}$ \\
\hline
\end{tabular}




\begin{tabular}{|c|c|c|c|}
\hline \multirow[b]{2}{*}{ Item Description } & \multicolumn{3}{|c|}{ Confirmatory Factor analysis } \\
\hline & $\begin{array}{c}\text { Initial } \\
\text { Sample } \\
(n=246) \\
\text { Loadings }\end{array}$ & $\begin{array}{c}\text { Validation } \\
\text { Sample } \\
\text { (Loadings) } \\
(\mathrm{n}=\mathbf{2 4 5 )}\end{array}$ & t-values \\
\hline \multicolumn{4}{|l|}{ Factor 1 Process Identity (PI) } \\
\hline Item 6 The behaviour of staff delivering brand $\mathrm{X}$ & 0.75 & 0.81 & 27.352 \\
\hline Item 12 The expertise of staff working for brand $\mathrm{X}$ & 0.79 & 0.84 & 33.298 \\
\hline Item 14 The quality of interaction with staff delivering brand $\mathrm{X}$ & 0.72 & 0.85 & 47.987 \\
\hline Item 21 The quality of the service provided by brand $\mathrm{X}$ & 0.78 & 0.82 & 33.541 \\
\hline Item 29 The consistency of service of brand X & 0.82 & 0.8 & 26.318 \\
\hline \multicolumn{4}{|l|}{ Factor 2 Organization Identity (OI) } \\
\hline Item 31 The company vision associated with brand $X$ & 0.76 & 0.9 & 82.74 \\
\hline Item 33 Your relationship with other customers using brand $\mathrm{X}$ & 0.84 & 0.82 & 32.37 \\
\hline Item 34 The social responsibility projected by brand $\mathrm{X}$ & 0.68 & 0.87 & 37.631 \\
\hline \multicolumn{4}{|l|}{ Factor 3 Symbolic Identity (SyI) } \\
\hline Item 1 The name of brand $X$ & 0.86 & 0.82 & 32.069 \\
\hline Item 2 The logo or symbols used to identify brand $\mathrm{X}$ & 0.81 & 0.86 & 43.497 \\
\hline Item 7 The colour(s) associated with brand $\mathrm{X}$ & 0.72 & 0.8 & 24.822 \\
\hline Item 8 The country of origin of brand $\mathrm{X}$ & 0.64 & 0.6 & 10.056 \\
\hline \multicolumn{4}{|l|}{ Factor 4 Servicescape Identity (SI) } \\
\hline Item 13 The appearance of the delivery environment used by brand $\mathrm{X}$ & 0.69 & 0.83 & 26.357 \\
\hline Item 27 The ambience in brand X's delivery environment & 0.88 & 0.88 & 49.101 \\
\hline Item 32 The general environment in which brand $\mathrm{X}$ is delivered & 0.87 & 0.88 & 35.043 \\
\hline \multicolumn{4}{|l|}{ Factor 5 Communication Identity (CI) } \\
\hline Item 20 Promotions carried out by brand $\mathrm{X}$ & 0.81 & 0.88 & 38.141 \\
\hline Item 22 The value-added benefits offered by brand $X$ & 0.74 & 0.92 & 98.245 \\
\hline $\begin{array}{l}\text { Model Fit } \\
\text { SRMR }\end{array}$ & 0.05 & & 0.06 \\
\hline NFI & 0.80 & & 0.78 \\
\hline
\end{tabular}


Table 4 Correlation Matrix (Study 2)

\begin{tabular}{|c|c|c|c|c|c|c|c|c|c|c|}
\hline $\begin{array}{l}\text { Validation } \\
\text { Sample } \\
(\text { Study } \\
(\mathrm{n}=245)\end{array}$ & $\begin{array}{l}\text { Cronbach's } \\
\text { Alpha }\end{array}$ & $\begin{array}{l}\text { Composite } \\
\text { Reliability } \\
\text { (CR) }\end{array}$ & $\begin{array}{l}\text { Average } \\
\text { Variance } \\
\text { Extracted } \\
\text { (AVE) }\end{array}$ & $\begin{array}{l}\text { Brand } \\
\text { Loyalty }\end{array}$ & $\begin{array}{l}\text { Brand } \\
\text { Trust }\end{array}$ & PI & OI & SyI & SI & CI \\
\hline $\begin{array}{l}\text { Brand } \\
\text { Loyalty }\end{array}$ & 0.87 & 0.91 & 0.67 & $(0.82)$ & & & & & & \\
\hline Brand Trust & 0.84 & 0.89 & 0.68 & 0.71 & $(0.82)$ & & & & & \\
\hline PI & 0.89 & 0.92 & 0.68 & 0.41 & 0.43 & $(0.83)$ & & & & \\
\hline OI & 0.84 & 0.90 & 0.75 & 0.46 & 0.52 & 0.49 & $(0.87)$ & & & \\
\hline SyI & 0.78 & 0.86 & 0.61 & 0.39 & 0.48 & 0.34 & 0.59 & (0.78) & & \\
\hline SI & 0.83 & 0.90 & 0.75 & 0.47 & 0.53 & 0.63 & 0.69 & 0.55 & $(0.87)$ & \\
\hline CI & 0.78 & 0.90 & 0.82 & 0.39 & 0.39 & 0.34 & 0.55 & 0.42 & 0.53 & $(0.91)$ \\
\hline
\end{tabular}

Note. Square root of average variance extracted (AVE) is reported on the diagonal. PI=Process Identity, OI=Organization Identity, SyI=Symbolic Identity, SI=Servicescape Identity, CI=Communication Identity. 


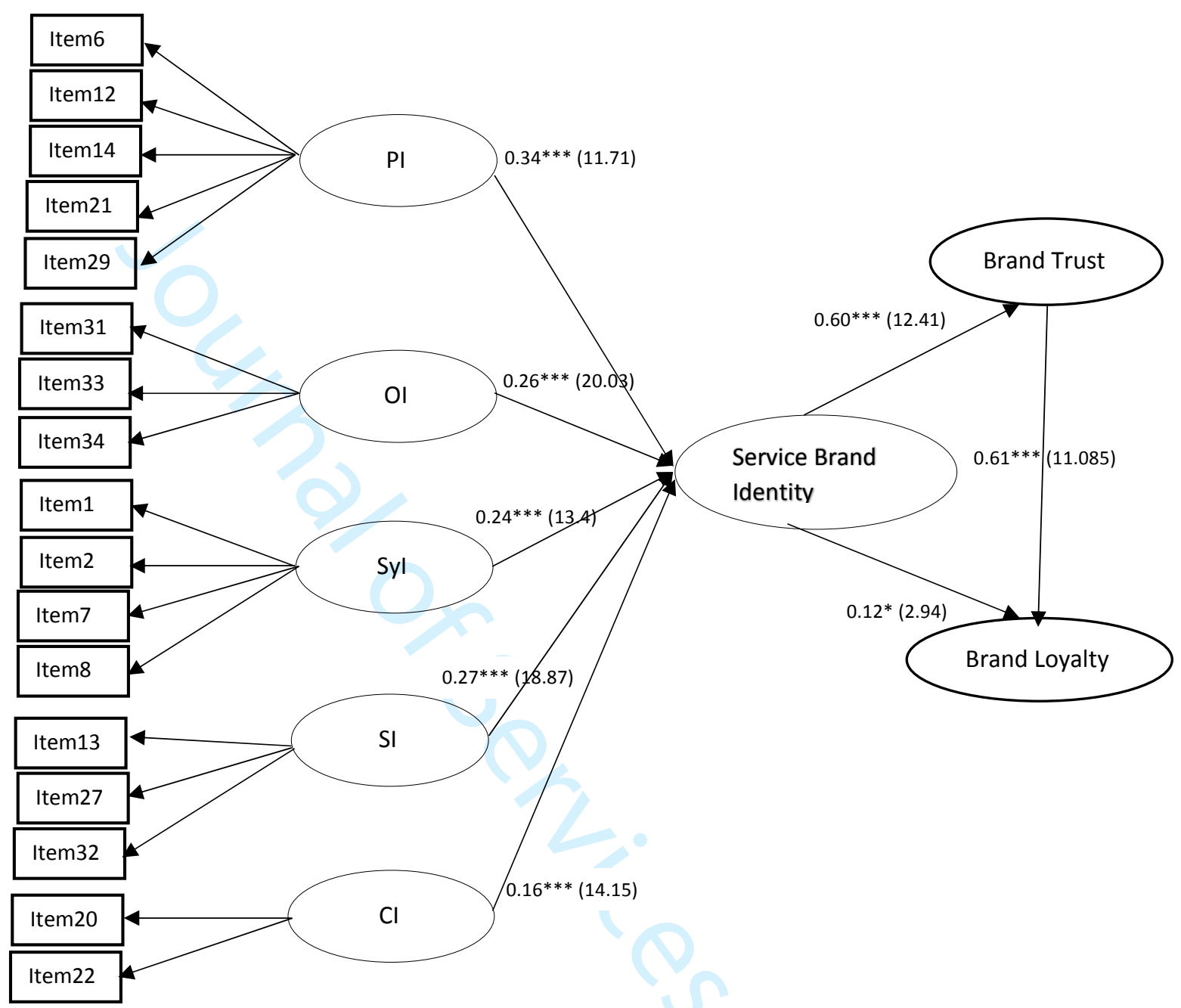

Figure 1 Confirmatory factorial analysis: Brand Identity as a second-order construct

The values for the first-order dimensions of brand identity are path coefficients, and parentheses show t-values. Path coefficients and $t$ values for the reflective indicators are provided separately in Table 5. (Acronyms: PI=Process Identity; $\mathrm{OI}=$ Organization Identity; SyI=Symbolic Identity; SI=Servicescape Identity; CI=Communication Identity) 


\section{Appendices}

\section{Appendix A: Dimensions/components of academic brand identity models}

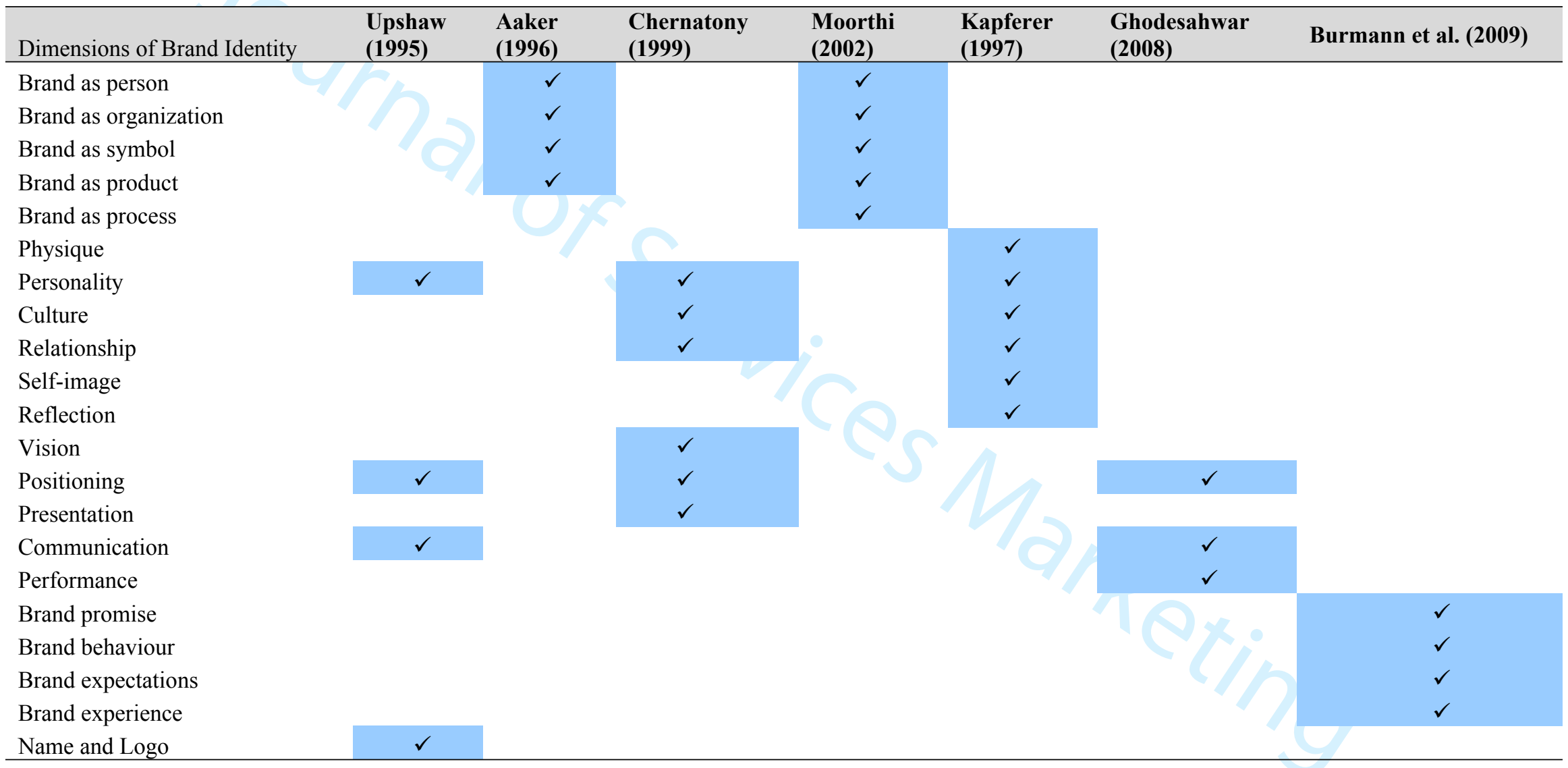




\section{Appendix B: The SERVBID Instrument ${ }^{1}$}

This survey seeks your opinion regarding factors that contribute in building a strong brand identity for brand

The following questions seek your level of agreement or disagreement, on a scale of 1 to 7 , with the following statements related to brand There are no right or wrong answers for this. We are primarily interested in your opinion and in the numbers that best highlight your level of agreement or disagreement.

On a scale of 1 to 7 with ' 1 ' meaning strongly disagree and '7' meaning strongly agree, please indicate the extent to which you agree or disagree that each of the following contribute in building brand identity for brand

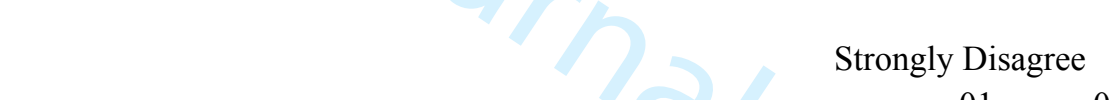

$01 \quad 02$

03

04

05

06

Strongly Agree

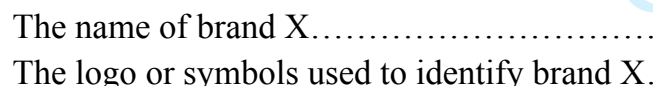

The colour(s) used by brand X......

The country of origin of brand $\mathrm{X}$

The company vision associated with brand $\mathrm{X}$.

Your relationship with other customers using brand $\mathrm{X}$

The social responsibility projected by brand $\mathrm{X}$.

The behaviour of staff delivering brand $\mathrm{X}$....

The expertise of staff working for brand $\mathrm{X}$.

The quality of interactions with staff delivering brand $\mathrm{X}$

The consistency of service of brand X....

The appearance of the delivery environment used by brand $\mathrm{X}$..

The ambience in brand X's delivery environment.

Promotions carried out by brand $\mathrm{X}$.

The quality of service provided by brand $\mathrm{X}$.

The value-added benefits offered by brand $\mathrm{X}$.

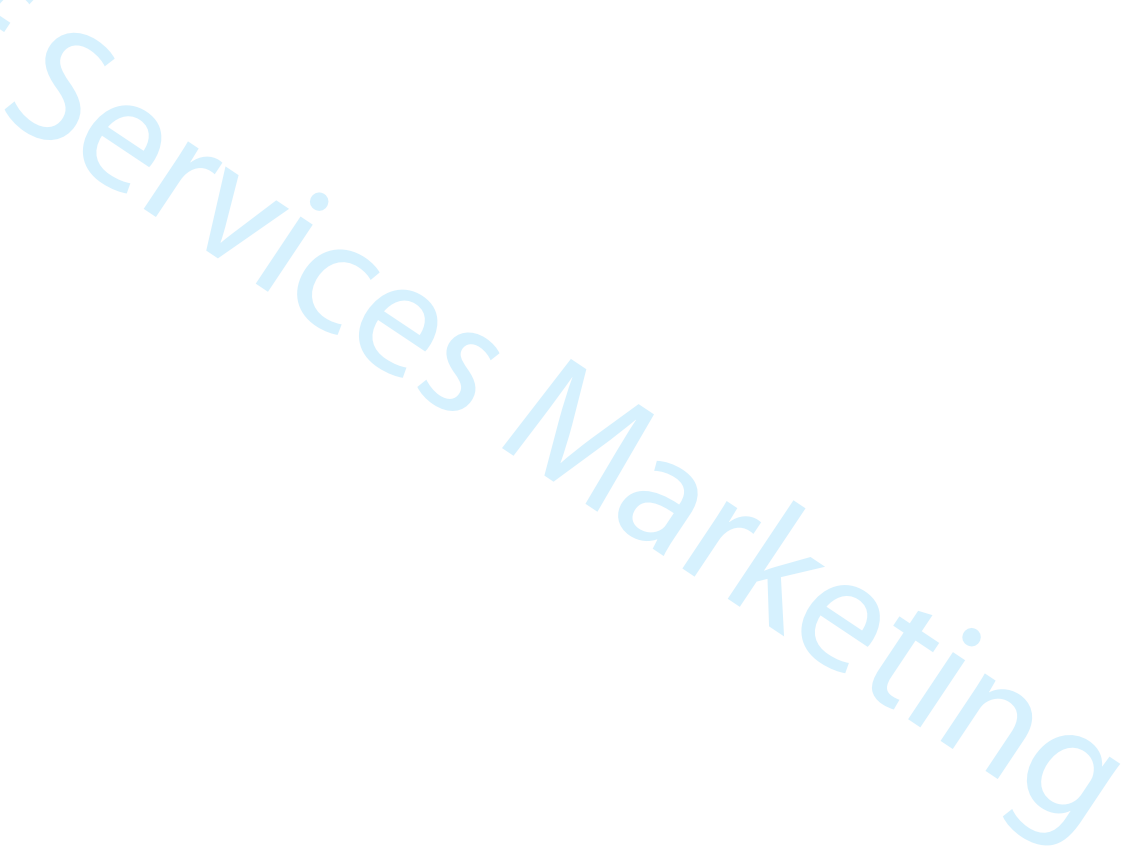

${ }^{1}$ This SERVBID scale can be used by surveying consumers using the 17 items (scored from 1 to 7 ) and summing the values obtained for each dimension and for the overall service brand identity construct. The minimum SERVBID score can be 17 and maximum score can be 119 . Independent scores can also be obtained for each of the five scale dimensions, which will help identify areas (with low scores) that need further development. 
Response to Reviewers' Comments

\begin{tabular}{|c|c|}
\hline Reviewer 2 Comments & Author Response \\
\hline $\begin{array}{l}\text { The author(s) have done a fine job with their } \\
\text { revision opportunity. As a result, the contribution to } \\
\text { the literature and fit with the JSM mission have } \\
\text { been meaningfully improved. My biggest concerns } \\
\text { have been adequately addressed. I believe the } \\
\text { manuscript will be well-received by the JSM } \\
\text { readership. Job well done! }\end{array}$ & Thank you for the comment. \\
\hline $\begin{array}{l}\text { Does the paper contain new and significant } \\
\text { information adequate to justify publication?: I } \\
\text { think so; the revision effort proved successful in } \\
\text { this regard. }\end{array}$ & Thank you for the comment. \\
\hline $\begin{array}{l}\text { Relationship to Literature: Does the paper } \\
\text { demonstrate an adequate understanding of the } \\
\text { relevant literature in the field and cite an } \\
\text { appropriate range of literature sources? Is any } \\
\text { significant work ignored?: Yes; the literature } \\
\text { review is robust and thorough. }\end{array}$ & Thank you for the comment. \\
\hline $\begin{array}{l}\text { Methodology: Is the paper's argument built on an } \\
\text { appropriate base of theory, concepts, or other } \\
\text { ideas? Has the research or equivalent intellectual } \\
\text { work on which the paper is based been well } \\
\text { designed? Are the methods employed appropriate?: } \\
\text { The method employed appears effective. }\end{array}$ & Thank you for the comment. \\
\hline $\begin{array}{l}\text { Results: Are results presented clearly and analysed } \\
\text { appropriately? Do the conclusions adequately tie } \\
\text { together the other elements of the paper?: Yes. }\end{array}$ & Thank you for the comment. \\
\hline $\begin{array}{l}\text { Implications for research, practice and/or } \\
\text { society: Does the paper identify clearly any } \\
\text { implications for research, practice and/or } \\
\text { society? Does the paper bridge the gap between } \\
\text { theory and practice? How can the research be used } \\
\text { in practice (economic and commercial impact), in } \\
\text { teaching, to influence public policy, in research } \\
\text { (contributing to the body of knowledge)? What is } \\
\text { the impact upon society (influencing public } \\
\text { attitudes, affecting quality of life)? Are these } \\
\text { implications consistent with the findings and } \\
\text { conclusions of the paper?: This area of the } \\
\text { manuscript is much improved from the original } \\
\text { submission. As a result, the fit with the JSM } \\
\text { mission is apparent. }\end{array}$ & Thank you for the comment. \\
\hline $\begin{array}{l}\text { Quality of Communication: Does the paper clearly } \\
\text { express its case, measured against the technical } \\
\text { language of the field and the expected knowledge } \\
\text { of the journal's readership? Has attention been paid } \\
\text { to the clarity of expression and readability, such as } \\
\text { sentence structure, jargon use, acronyms, etc.: The }\end{array}$ & Thank you for the comment. \\
\hline
\end{tabular}


story reads well.

\begin{tabular}{|c|c|}
\hline Reviewer 1 Comments & Author Response \\
\hline $\begin{array}{l}\text { Thank you for your very thorough revision. I } \\
\text { believe you have taken all the appropriate measures } \\
\text { to address my original concerns about this } \\
\text { manuscript with the exception of one small area. I } \\
\text { refer to the construct definition. You provide a } \\
\text { broad definition of brand identity that has been } \\
\text { adopted for this study. However, you provide no } \\
\text { actually definition for your construct "Service } \\
\text { Brand Identity". What you are actually arguing } \\
\text { through the paper is that Service Brand Identity is } \\
\text { the sum of process, organizational, symbolic, } \\
\text { servicescape and communication attributes that } \\
\text { form the identity of the service brand. Please make } \\
\text { sure you provide a specific definition of SBI that } \\
\text { includes your identified dimensions. }\end{array}$ & $\begin{array}{l}\text { We have added the following construct } \\
\text { definition at the start of the conclusion (p.21): } \\
\text { "We propose a novel and more inclusive } \\
\text { definition of the construct of Service Brand } \\
\text { Identity conceptualized as: the sum of } \\
\text { process, organizational, symbolic, } \\
\text { servicescape and communication attributes } \\
\text { that define the brand, give it distinguishable } \\
\text { features and make it recognizable." }\end{array}$ \\
\hline $\begin{array}{l}\text { Originality: Does the paper contain new and } \\
\text { significant information adequate to justify } \\
\text { publication?: Yes. }\end{array}$ & Thank you for the comment \\
\hline $\begin{array}{l}\text { Relationship to Literature: Does the paper } \\
\text { demonstrate an adequate understanding of the } \\
\text { relevant literature in the field and cite an } \\
\text { appropriate range of literature sources? Is any } \\
\text { significant work ignored?: Literature is thorough } \\
\text { and appropraite }\end{array}$ & \\
\hline $\begin{array}{l}\text { Methodology: Is the paper's argument built on an } \\
\text { appropriate base of theory, concepts, or other } \\
\text { ideas? Has the research or equivalent intellectual } \\
\text { work on which the paper is based been well } \\
\text { designed? Are the methods employed appropriate?: } \\
\text { Yes - but please see overall comment }\end{array}$ & Thank you for the comment \\
\hline $\begin{array}{l}\text { Results: Are results presented clearly and analysed } \\
\text { appropriately? Do the conclusions adequately tie } \\
\text { together the other elements of the paper?: Yes }\end{array}$ & Thank you for the comment \\
\hline $\begin{array}{l}\text { Implications for research, practice and/or } \\
\text { society: Does the paper identify clearly any } \\
\text { implications for research, practice and/or } \\
\text { society? Does the paper bridge the gap between } \\
\text { theory and practice? How can the research be used } \\
\text { in practice (economic and commercial impact), in } \\
\text { teaching, to influence public policy, in research } \\
\text { (contributing to the body of knowledge)? What is }\end{array}$ & Thank you for the comment \\
\hline
\end{tabular}


the impact upon society (influencing public attitudes, affecting quality of life)? Are these implications consistent with the findings and conclusions of the paper?: Yes

Quality of Communication: Does the paper clearly $\quad$ Thank you for the comment express its case, measured against the technical language of the field and the expected knowledge of the journal's readership? Has attention been paid to the clarity of expression and readability, such as sentence structure, jargon use, acronyms, etc.: High quality

\begin{tabular}{|l|l|}
\hline Reviewer 3 Comments & Author Response \\
\hline $\begin{array}{l}\text { The authors have made substantial strides in } \\
\text { clarity and organization of the paper. The shift } \\
\text { to a first order reflective, second order formative } \\
\text { construct for BI made a huge difference (in my } \\
\text { view) in the ability to understand the model, the } \\
\text { analyses, and the implications. My comments at } \\
\text { this point primarily focus on minor and easily } \\
\text { addressable issues. }\end{array}$ & Thank you for the comment \\
\hline $\begin{array}{l}\text { Page } 3 \text { - The sentence about contributing to the } \\
\text { literature on brand identity should either place } \\
\text { an "e.g.," inside of the citations, as these are } \\
\text { examples of the literature on brand identity, or } \\
\text { the citation should be removed as they are fairly } \\
\text { unnecessary in this statement. }\end{array}$ & \\
\hline $\begin{array}{l}\text { Page } 8 \text { - Be consistent in your use of } \% \text { or } \\
\text { percent (follow journal guidelines). Also, "per } \\
\text { cent" should be percent. }\end{array}$ & 'Per cent' changed to '\%'” \\
\hline $\begin{array}{l}\text { Page } 9 \text { - The first line should read ..."that each } \\
\text { of the items (statements) contribute..." }\end{array}$ & Change done in-text \\
$\begin{array}{l}\text { Page } 9 \text { - Also, "Hows } \\
\text { adding "a" into the sentence apart from a few..." }\end{array}$ & Added 'a' \\
\hline $\begin{array}{l}\text { Be sure to recheck citations. Sometimes } \\
\text { commas are being used and sometimes they are } \\
\text { not. Additionally, there is often no order to the } \\
\text { citations. Follow journal guidelines for citations } \\
\text { throughout. }\end{array}$ & All in-text citations checked for consistency \\
\hline
\end{tabular}


Page 12 - please provide a slightly deeper explanation of the result of Brand-as-Product and Brand-as-Experience being subsumed into process and servicescape dimensions. Offer some examples or further information beyond offerings being experienced as a process delivered via a service environment. Use the items as examples to make this case a little easier to accept functionally.
We have extended the explanation as follows (on p.12):

"The originally proposed facets Brand-asProduct and Brand-as-Experience did not emerge as distinct dimensions; the retained items making up these dimensions were subsumed into other dimensions, reflecting the intangibility of the service offering (product) as largely experienced as a process and emphasising the role of communication and symbolic representation of the brand. For example, the items originally proposed in the Brand-asExperience facet (e.g. 'Your relationship with the people providing brand $\mathrm{X}$ ' and 'Your relationship with other customers using brand $\mathrm{X}^{\prime}$ ), were subsumed into the Brand-as-Process dimension. Items originally proposed under the Brand-as-Product facet were subsumed into the Brand-as-Symbol dimension (e.g. 'The country of origin of brand $X^{\prime}$ '), and the Brand-asCommunication dimension (e.g. 'The valueadded benefits offered by brand X')."

It appears as though Table 4 is mislabeled given the discussion around it. Unless I've misunderstood something at the top of page 8 , the final dimension to be listed should be "Brand as Service Process" and the second to last dimension should be "Brand-as-ServiceProcess" rather than "Brand-As-ServiceExperience."

Figure 2 seems unnecessary given Figure 1. Figure 1 should simply be updated to either spell out the constructs in the model or annotate at the bottom the meaning of each acronym.

Originality: Does the paper contain new and significant information adequate to justify publication?: The development of a brand identity scale represents a modest advancement in the ability to measure brand identity. Gains are primarily made through considering service dominant logic and the inclusion of process identity and servicescape identity. These adaptations and extensions merit publication in a services journal like JSM.
We've removed Table 4, because, on reflection, it wasn't saying any more than was already said in the paper, and was clearly causing confusion.
Figure 2 removed;

Meaning of each acronym used in figure 1 added at the bottom as follows:

"(Acronyms: PI=Process Identity; OI= Organization identity; SyI=Symbolic Identity; SI=Servicescape Identity; CI=Communication Identity)"

Thank you for your comment 
Relationship to Literature: Does the paper demonstrate an adequate understanding of the relevant literature in the field and cite an appropriate range of literature sources? Is any significant work ignored?: The foundational literature is adequately covered and overlaps among different areas are highlighted. Extensions of BI into services are justified through literature and expert rater evaluation.

Methodology: Is the paper's argument built on Thank you for your comment an appropriate base of theory, concepts, or other ideas? Has the research or equivalent intellectual work on which the paper is based been well designed? Are the methods employed appropriate?: The methods have been suitably updated and explained. For example, the primary construct for $\mathrm{BI}$ is now formative rather than reflective and sub components are shown to be reflective.

Results: Are results presented clearly and analysed appropriately? Do the conclusions adequately tie together the other elements of the paper?: The whole paper is much clearer, including the results.

Implications for research, practice and/or society: Does the paper identify clearly any implications for research, practice and/or society? Does the paper bridge the gap between theory and practice? How can the research be used in practice (economic and commercial impact), in teaching, to influence public policy, in research (contributing to the body of knowledge)? What is the impact upon society (influencing public attitudes, affecting quality of life)? Are these implications consistent with the findings and conclusions of the paper?:

Following reviewer comments the implications have been much better fleshed out. Research and practice are much clearer and value added in this revision.

Quality of Communication: Does the paper clearly express its case, measured against the technical language of the field and the expected knowledge of the journal's readership? Has attention been paid to the clarity of expression and readability, such as sentence structure, jargon use, acronyms, etc.: Overall, the communication quality has increased, though 
there are some minor issues I point out to the author(s). 
SERVBID: The Development of a B2C Service Brand Identity Scale

Online (only) Appendices

\section{Appendix C SERVBID Scale Development Process}

\begin{tabular}{|c|c|c|c|}
\hline $\begin{array}{l}\text { Scale Development } \\
\text { Stage }\end{array}$ & Purpose & Action & Design \\
\hline $\begin{array}{l}\text { Specify domain of } \\
\text { construct }\end{array}$ & $\begin{array}{l}\text { To determine what } \\
\text { to measure; to set } \\
\text { boundaries of what } \\
\text { the scale can or } \\
\text { cannot measure }\end{array}$ & $\begin{array}{l}\text { Proposed preliminary } \\
\text { definition of brand identity. } \\
\text { Postulated dimensions of brand } \\
\text { identity as given in the } \\
\text { literature. }\end{array}$ & Qualitative \\
\hline $\begin{array}{l}\text { Generate an item } \\
\text { pool }\end{array}$ & $\begin{array}{l}\text { To develop a set of } \\
\text { items to capture } \\
\text { each dimension of } \\
\text { brand identity }\end{array}$ & $\begin{array}{l}\text { Generated items from } \\
\text { literature. } \\
\text { Generated items and three new } \\
\text { dimensions through in-depth } \\
\text { consumer interviews. }\end{array}$ & Qualitative \\
\hline $\begin{array}{l}\text { Refine Items } \\
\text { (Initial Item } \\
\text { Purification) }\end{array}$ & $\begin{array}{l}\text { To evaluate the } \\
\text { clarity, conciseness } \\
\text { and readability of } \\
\text { each item, thereby } \\
\text { establishing face } \\
\text { and content validity } \\
\text { of items }\end{array}$ & $\begin{array}{l}\text { Stage } 1 \& 2-\text { Items refined by } \\
\text { two independent marketing } \\
\text { academic experts; } 79 \text { items } \\
\text { reduced to } 47 \text { items. } \\
\text { Stage } 3 \text { - Items subjected to } \\
\text { review by a panel of } 10 \\
\text { academic experts within UK } \\
\text { and US; } 47 \text { items reduced to } 35 \\
\text { items. }\end{array}$ & Qualitative \\
\hline $\begin{array}{l}\text { Develop and pre- } \\
\text { test survey } \\
\text { (Pilot Study, } \\
\text { n=106) }\end{array}$ & $\begin{array}{l}\text { To further refine } \\
\text { the items, check } \\
\text { convergent validity } \\
\text { and to eliminate } \\
\text { items with low } \\
\text { factor loadings }\end{array}$ & $\begin{array}{l}35 \text { items pilot-tested in a } \\
\text { survey administered to a } \\
\text { sample of } 106 \text { participants. } \\
\text { Coefficient alpha and inter- } \\
\text { item correlations calculated to } \\
\text { check internal consistency. } \\
\text { EFA conducted; } 35 \text { items } \\
\text { reduced to } 29 \text { items for final } \\
\text { testing. }\end{array}$ & Quantitative \\
\hline $\begin{array}{l}\text { Administer final } \\
\text { survey to wider } \\
\text { sample } \\
\text { (Study 1, n=246) }\end{array}$ & $\begin{array}{l}\text { To develop the } \\
\text { SERVBID scale }\end{array}$ & $\begin{array}{l}\text { Survey administered to UK } \\
\text { consumer sample; Data from } \\
245 \text { responses refined through } \\
\text { coefficient alpha, inter-item } \\
\text { correlations, and EFA. } \\
\text { CFA conducted for confirming } \\
\text { the scale structure }\end{array}$ & Quantitative \\
\hline $\begin{array}{l}\begin{array}{l}\text { Cross-Validation } \\
\text { of scale }\end{array} \\
\text { (Study 2, n=245) }\end{array}$ & $\begin{array}{l}\text { To establish the } \\
\text { construct and } \\
\text { nomological } \\
\text { validity of the scale }\end{array}$ & $\begin{array}{l}\text { Conducted cross validation to } \\
\text { establish construct and } \\
\text { nomological validity. } \\
\text { SERVBID scale applied to test } \\
\text { impact on brand trust and } \\
\text { loyalty using PLS SEM }\end{array}$ & Quantitative \\
\hline
\end{tabular}




\section{Appendix D Brand Identity dimensions from literature and consumer interviews}

\begin{tabular}{lll}
\hline Dimension & Description & Source \\
\hline Brand-as-Symbol & $\begin{array}{l}\text { It encapsulate elements that deal with outer } \\
\text { appearance of a brand, its name, logo, symbol, } \\
\text { slogan, packaging, presentation and metaphors }\end{array}$ & $\begin{array}{l}\text { Literature + Validated } \\
\text { through Consumer } \\
\text { Interviews }\end{array}$ \\
\hline Brand-as-Product & $\begin{array}{l}\text { It includes product related aspects that can } \\
\text { contribute to building of a brand identity, for e.g. } \\
\text { product attributes, quality, uses and users }\end{array}$ & $\begin{array}{l}\text { Literature + Validated } \\
\text { through Consumer } \\
\text { Interviews }\end{array}$ \\
\hline $\begin{array}{l}\text { Brand-as- } \\
\text { Organization }\end{array}$ & $\begin{array}{l}\text { It includes organization related aspects that can } \\
\text { contribute in building brand identity, like }\end{array}$ & $\begin{array}{l}\text { Literature + Validated } \\
\text { through Consumer }\end{array}$ \\
& $\begin{array}{l}\text { innovation, vision, company culture, social } \\
\text { responsibility initiatives }\end{array}$ & Interviews \\
\hline $\begin{array}{l}\text { Brand-as- } \\
\text { communication }\end{array}$ & $\begin{array}{l}\text { It includes aspects like positioning, advertising, } \\
\text { celebrity endorsement, promotion, and peer }\end{array}$ & $\begin{array}{l}\text { Literature + Validated } \\
\text { through Consumer } \\
\text { influence }\end{array}$ \\
\hline $\begin{array}{l}\text { Brand-as- } \\
\text { Servicescape }\end{array}$ & $\begin{array}{l}\text { It includes elements like service environment, } \\
\text { ambience and site, atmosphere, and facilities }\end{array}$ & Consumer Interviews \\
\hline $\begin{array}{l}\text { Brand-as-Service } \\
\text { Experience }\end{array}$ & $\begin{array}{l}\text { It includes elements of consumer experience, and } \\
\text { reputation }\end{array}$ & Consumer Interviews \\
\hline $\begin{array}{l}\text { Brand-as-Service } \\
\text { Communication }\end{array}$ & $\begin{array}{l}\text { It includes aspects like positioning, advertising, } \\
\text { celebrity endorsement, promotion, and peer } \\
\text { influence }\end{array}$ & Consumer Interviews \\
\hline & & \\
\hline
\end{tabular}


Appendix E Initial Item Pool (after Pilot Testing)

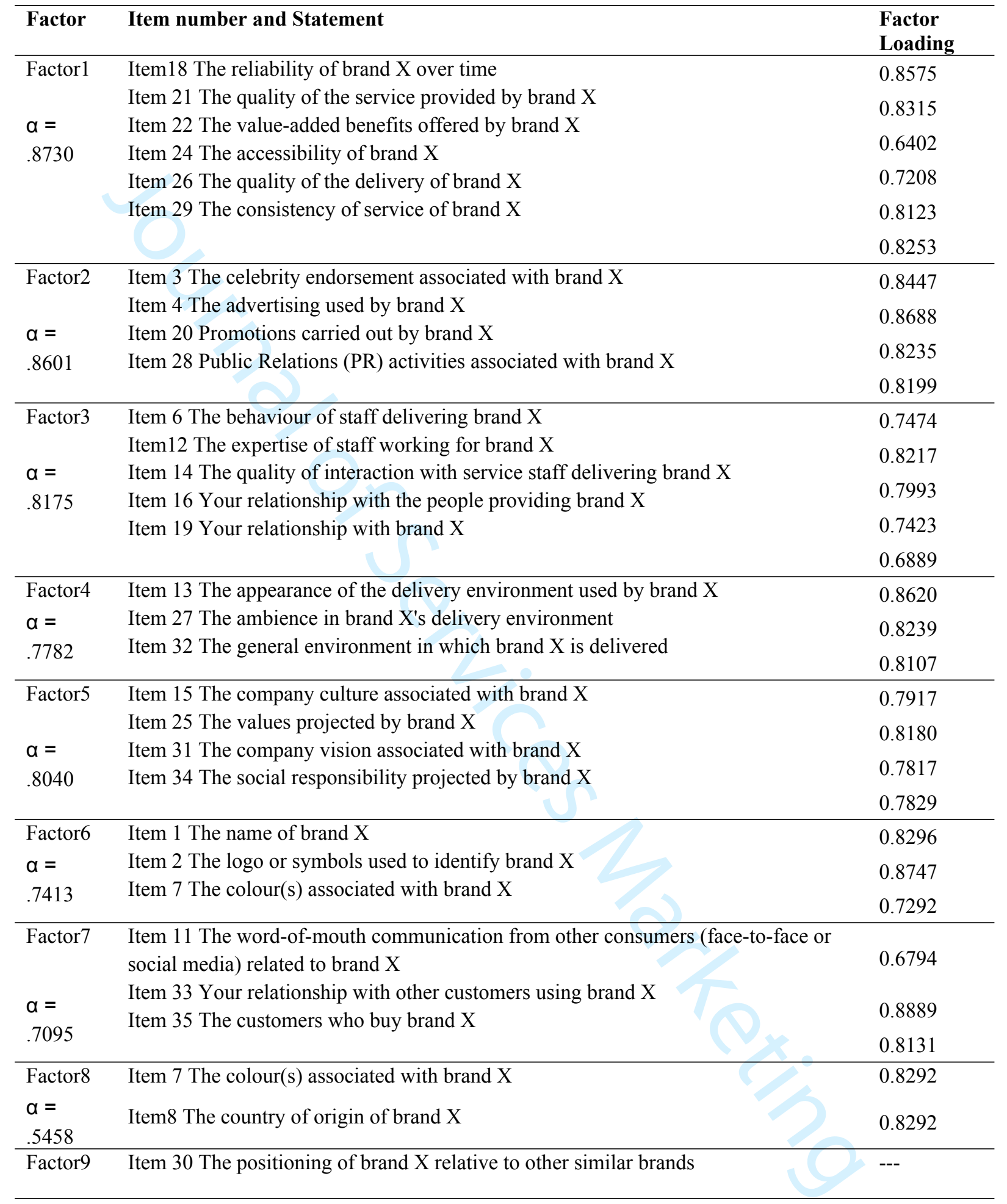

Items Candidate for Deletion (did not load on any factor)

Item5 The distinctiveness of brand $\mathrm{X}$

Item9 The reputation of brand $\mathrm{X}$

Item10 Your prior experience with brand $\mathrm{X}$

Item 17 The facilities available in brand X's delivery environment

Item 23 The personality of brand $\mathrm{X}$ 


\section{Appendix F: List of items that were dropped and items that were retained following EFA}

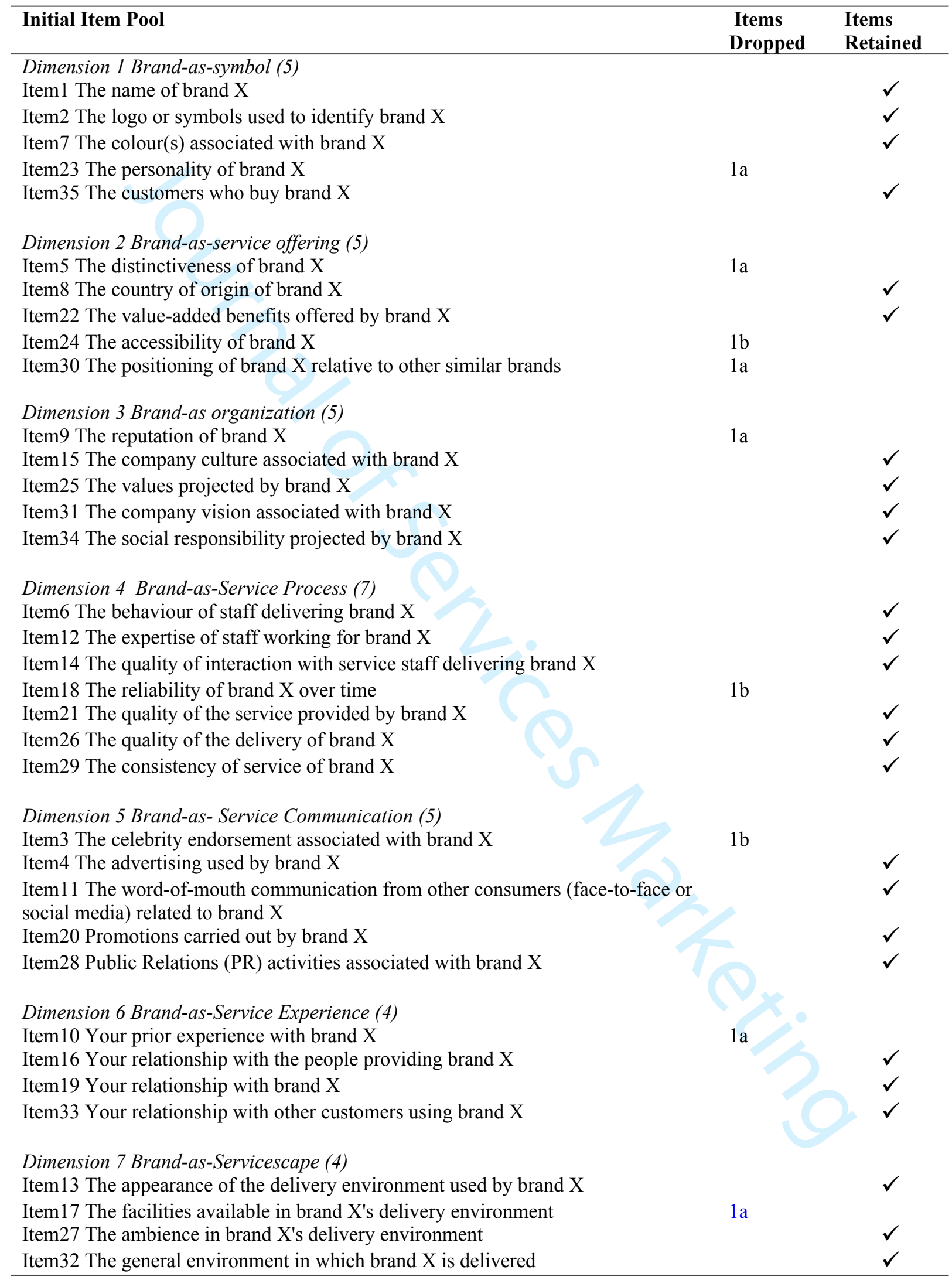

Items Dropped: $1 \mathrm{a}=$ in the initial item purification through pilot testing; $1 \mathrm{~b}=$ after exploratory factor analysis (study1) ; "Items Retained" column shows items that were retained for the Confirmatory Factor Analysis 
Appendix G: Total Variance Explained

\begin{tabular}{|c|c|c|c|c|c|c|}
\hline \multirow[t]{2}{*}{ Component } & \multicolumn{3}{|c|}{ Initial Eigenvalues } & \multicolumn{3}{|c|}{ Rotation Sums of Squared Loadings } \\
\hline & Total & $\begin{array}{r}\% \text { of } \\
\text { Variance }\end{array}$ & Cumulative \% & Total & $\begin{array}{r}\% \text { of } \\
\text { Variance }\end{array}$ & Cumulative \% \\
\hline 1 & 10.56 & 40.60 & 40.60 & 5.54 & 21.30 & 21.30 \\
\hline 2 & 3.08 & 11.85 & 52.45 & 3.68 & 14.17 & 35.47 \\
\hline 3 & 1.68 & 6.46 & 58.91 & 3.53 & 13.58 & 49.04 \\
\hline 4 & 1.20 & 4.62 & 63.53 & 2.55 & 9.82 & 58.86 \\
\hline 5 & 1.06 & 4.09 & 67.62 & 2.28 & 8.76 & 67.62 \\
\hline 6 & 0.87 & 3.35 & 70.98 & & & \\
\hline 7 & 0.74 & 2.85 & 73.82 & & & \\
\hline 8 & 0.65 & 2.49 & 76.32 & & & \\
\hline 9 & 0.63 & 2.44 & 78.75 & & & \\
\hline 10 & 0.60 & 2.30 & 81.05 & & & \\
\hline 11 & 0.48 & 1.86 & 82.91 & & & \\
\hline 12 & 0.46 & 1.76 & 84.67 & & & \\
\hline 13 & 0.43 & 1.64 & 86.31 & & & \\
\hline 14 & 0.41 & 1.59 & 87.90 & & & \\
\hline 15 & 0.39 & 1.50 & 89.40 & & & \\
\hline 16 & 0.34 & 1.31 & 90.71 & & & \\
\hline 17 & 0.33 & 1.25 & 91.96 & & & \\
\hline 18 & 0.32 & 1.23 & 93.19 & & & \\
\hline 19 & 0.30 & 1.16 & 94.35 & & & \\
\hline 20 & 0.28 & 1.09 & 95.44 & & & \\
\hline 21 & 0.24 & 0.92 & 96.35 & & & \\
\hline 22 & 0.22 & 0.86 & 97.21 & & & \\
\hline 23 & 0.21 & 0.80 & 98.01 & & & \\
\hline 24 & 0.19 & 0.71 & 98.72 & & & \\
\hline 25 & 0.18 & 0.68 & 99.40 & & & \\
\hline 26 & 0.16 & 0.60 & 100.00 & & & \\
\hline
\end{tabular}

